Luciana Paroneto Medina

\title{
Modulação da morte mediada por FAS em células Tipo I e Tipo II
}

\author{
Dissertação apresentada ao \\ Departamento de Imunologia do \\ Instituto de Ciências Biomédicas da \\ Universidade de São Paulo para \\ obtenção do Título de Mestre em \\ Ciências.
}




\section{Modulação da morte mediada por FAS em células Tipo I e Tipo II}

Dissertação apresentada ao Departamento de Imunologia do Instituto de Ciências Biomédicas da Universidade de São Paulo para obtenção do Título de Mestre em Ciências.

Área de concentração: Imunologia

Orientador: Prof. Dr. João Gustavo Pessini Amarante-Mendes

Versão original 
DADOS DE CATALOGAÇÃO NA PUBLICAÇÃO (CIP)

Serviço de Biblioteca e Informação Biomédica do

Instituto de Ciências Biomédicas da Universidade de São Paulo

(C) reprodução total

Medina, Luciana Paroneto.

Modulação da morte mediada por FAS em células Tipo I e Tipo II / Luciana Paroneto Medina. -- São Paulo, 2011.

Orientador: João Gustavo Pessini Amarante-Mendes.

Dissertação (Mestrado) - Universidade de São Paulo. Instituto de Ciências Biomédicas. Departamento de Imunologia. Área de concentração: Imunologia. Linha de pesquisa: Morte celular.

Versão do título para o inglês: Modulation of FAS-mediated death in Type I and Type II cells

Descritores: 1. Apoptose 2. FAS/FASL 3 . Células Tipo I e Tipo II 4. Prostaglandina $E_{2} \quad$ I. Amarante-Mendes, João Gustavo Pessini II. Universidade de São Paulo. Instituto de Ciências Biomédicas.

Programa de Pós-Graduação em Imunologia III. Título. 
A Comissão Julgadora dos trabalhos de Defesa da Dissertação de Mestrado, em sessão pública realizada a

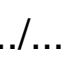
considerou
( ) Aprovado(a)
( ) Reprovado(a)

Examinador(a): Assinatura:

Nome:

Instituição:

Examinador(a): Assinatura:

Nome:

Instituição:

Presidente: Assinatura:

Nome:

Instituição: 
Aos meus queridos pais,

Hilton e Nair, a quem serei eternamente grata por tudo. 


\section{AGRADECIMENTOS}

Em primeiro lugar, gostaria de agradecer aos meus queridos pais, Hilton e Nair, pois sem o apoio e a compreensão deles, esse objetivo jamais seria alcançado. Obrigada por tudo. Um dia gostaria de retribuir tudo que o que fizeram por mim, mas infelizmente, sei que isso será impossível. Agradeço também aos meus queridos irmãos, Fabiana e Fernando, que sempre me ajudaram e me apoiaram para que hoje eu estivesse aqui. Minha família, com certeza, faz toda a diferença na minha vida.

Agradeço aos meus familiares e amigos que podem não ter contribuído diretamente para o meu mestrado, mas que sempre estiveram ao meu lado, me proporcionando bons momentos de distração, me incentivando e torcendo tanto por mim, em especial, a Tia Dalva, minha segunda mãe, a Carol, Gabriela, Vick, Marcos, Fê, Prin e Jessie.

Agradeço ao meu orientador, Gustavo, por ter me dado a grande oportunidade de fazer parte desse grupo. Tenho muito orgulho disso. Agradeço também por todos os conselhos e broncas que me fizeram crescer muito durante todo esse tempo, por todas as conversas de incentivo quando as coisas pareciam não caminhar bem, por todas as vezes que saí de sua sala acreditando que poderia ser cada vez melhor e por todo o carinho que sempre tem conosco.

Agradeço a todos do laboratório que muito mais do que colegas, são meus amigos, minha segunda família. Dentre tantos motivos que tenho para agradecer a todos eles: ao Welbert que me recebeu tão bem quando cheguei ao laboratório e fez com que eu não me sentisse tão perdida, a Jackie pelo seu enorme coração, pela preocupação e por estar sempre disposta a ajudar, a Maria Emília, por todos os experimentos e discussões que compartilhamos e por tornar todos esses momentos tão divertidos, a Júlia por todo o carinho e atenção que me deu desde o primeiro dia, a Inaê, ao Rodolfo e a Flávia pelas horas de almoço mais divertidas que já tive e também por todas as discussões de imuno que são tão produtivas, ao Tiago por sempre conversar comigo e conseguir me acalmar nos momentos de ansiedade e desespero, ao Juninho, que em tão pouco tempo mostrou o quanto é especial, a Bárbara por compartilhar conosco sua experiência de pós-doc e por sempre animar as festinhas, a Danielle por todas as dicas e sugestões com a 
apresentação, a Nathy, pela companhia em vários momentos, a Jaqueline Midori e a Cris, apesar do pouco tempo de convivência e ao Daniel por todas as atividades que realiza no laboratório e que facilitam o nosso trabalho.

Agradeço também a professora Karina e as suas alunas que em muitos momentos dividem o laboratório conosco: Thais, Silvia e Alexandra. Agradeço pela companhia de todos os dias e pela convivência tão prazerosa. Agradecimento especial a Carininha por todas as conversas jogadas fora, por todas as experiências compartilhadas e por tantas risadas.

Agradeço também àqueles que já saíram do laboratório, mas que marcaram presença e que fazem muita falta: ao André pelo almoço de todos os dias e pelas horas de sol após as refeições, a Lú Concepción por toda ajuda intelectual e todo o carinho desde sempre, a Dé que tanto me ajudou quando eu ainda estava no começo e que sempre teve tanta paciência pra me explicar e ensinar, ao Bruno e ao Dú por todos os momentos de diversão e descontração no laboratório e pela ajuda nos experimentos, ao Ricardo que simplesmente nunca estava ocupado demais para me dar atenção, me ajudar nos experimentos ou me explicar alguma coisa, a Maíra por ter me ajudado com tantas dúvidas de imuno antes de prestar a prova de ingresso, e a Mariana, Thainá, Nair, Gabriela e Danilo agradeço muito a todos eles. $E$ ainda tem aqueles com quem quase não tive tempo de conviver, mas com quem ainda pude aprender um pouquinho: Daniel, Moki, Claudinha e Aninha.

Agradeço ao meu Professor de Imunologia da graduação, Jefferson Russo Victor, pelas excelentes aulas dadas com tanto amor e paixão que me despertaram o interesse pela imunologia me fazendo entender o verdadeiro valor dessa ciência. Agradeço também a todos os meus amigos de faculdade que estavam comigo nesses momentos, Fernanda, Patrícia, Nicole, Marcela, Margarete, Wagner, Juliana e Mariane. Agradeço pelas melhores manhãs da minha vida!

E se eu agradeço aqueles que me fizeram ingressar nessa área, também agradeço aqueles que me fizeram acreditar que era possível continuar, sobretudo aos meus dois grandes amigos Fabian e Tiago. Se não fosse o grande apoio e as longas conversas talvez eu tivesse desistido no momento em que parecia que as coisas nunca iam dar certo. Hoje amo o que eu faço e sei que teria cometido um grande erro se tivesse desistido. 
Agradeço a minha banca de qualificação, professores Niels Olsen, Anderson Nunes e Roger Chammas, por todas as observações, dicas e sugestões que foram muito bem-vindas. E agradeço também a todos os professores que aceitaram fazer parte da minha banca de tese e que reservaram uma parte do seu precioso tempo para avaliar esse trabalho.

Agradeço a Universidade de São Paulo, onde desenvolvi este trabalho, sobretudo ao Departamento de Imunologia do Instituto de Ciências Biomédicas, onde pretendo permanecer por muito tempo ainda. Agradeço aos funcionários do departamento, ao pessoal da limpeza, por sempre deixar o ambiente de trabalho mais agradável, ao pessoal do audiovisual: Moisés e Márcio por estarem sempre dispostos a ajudar, aos porteiros: Otacílio, Milton, Aírton, Geraldo, Abelírio, Delman, Hênio e Nelson por me receberem sempre com tanta alegria todos os dias e por sempre me fazerem companhia até o carro nas vezes em que tive que sair mais tarde para que eu não fosse sozinha. Aos secretários, Amarildo, que infelizmente não se encontra mais entre nós, mas que sempre foi tão atencioso e prestativo, e a Eni, Tiago, Jotelma e Amanda também sempre muito atenciosos e dispostos a ajudar. Agradeço ainda aos funcionários da Biblioteca do ICB I, em especial, a Mônica, pela enorme atenção e simpatia na hora da correção da dissertação.

Agradeço aos professores e demais colegas de departamento por tudo que acrescentaram na minha formação e pela convivência durante estes quase três anos da minha vida.

Agradeço de forma muito importante também ao Apoio da FAPESP, CAPES e CNPq, agências de fomento que nos incentivam a continuar nossos trabalhos, que acreditam na nossa pesquisa e confiam em nosso potencial, sem eles nossas pesquisas não seriam possíveis.

E por fim agradeço a todos aqueles que acabei não citando, mas que de uma forma ou de outra contribuíram para que hoje eu estivesse aqui. 
"Nenhum estudante que deseja obter o sucesso pode realizar um ato sem saber por que 0 faz."

Autor desconhecido 


\section{RESUMO}

Medina LP. Modulação da morte mediada por FAS em células Tipo I e Tipo II. [Dissertação (Mestrado em Imunologia)]. São Paulo: Instituto de Ciências Biomédicas da Universidade de São Paulo; 2011.

A apoptose é um processo de morte celular que pode ser dividido, didaticamente, em duas vias: a via intrínseca e a via extrínseca. A sinalização induzida pela via extrínseca e mediada pelo receptor de morte FAS pode ocorrer de forma dependente ou independente da mitocôndria. Em células denominadas Tipo I, a interação entre FAS/FASL resulta na clivagem direta de caspase-3 pela caspase-8, enquanto que em células Tipo II, a caspase-8 cliva BID que promove uma amplificação mitocondrial para posterior ativação da caspase-3. É importante considerar que: 1) Resultados prévios do nosso grupo demonstraram que doses subletais de $\mathrm{CHX}$ foram capazes de sensibilizar células Tipo I e Tipo II à apoptose e de realizar a conversão de células Tipo II em Tipo I; 2) Um dos possíveis mecanismos envolvidos nessa conversão é o recrutamento da molécula FAS para as chamadas "balsas lipídicas" (membrane rafts), aumentando a eficiência da sinalização; 3) $\mathrm{A} \mathrm{PGE}_{2}$ pode ativar PKA, através do aumento de CAMP via receptores EP2 e EP4, que realiza a fosforilação da ezrina, uma das proteínas envolvidas no recrutamento de FAS para as balsas lipídicas; 4) A PGE 2 além de ser capaz de induzir apoptose em determinadas linhagens celulares, é capaz de sensibilizar outras ao processo de apoptose, de forma semelhante a CHX. Baseado nestes pontos, nós formulamos a hipótese de que a $\mathrm{PGE}_{2}$, graças a sua capacidade sensibilizadora poderia, de forma semelhante a $\mathrm{CHX}$, sensibilizar linhagens celulares ao processo de apoptose e realizar a conversão de células Tipo II em Tipo I. O efeito de sensibilização não foi observado em células DO11.10 nas quais a apoptose foi induzida por CD95L solúvel. Em linhagens celulares Tipo I e Tipo II, nas quais a apoptose foi induzida pelo anticorpo agonista anti-FAS também não houve efeito de sensibilização.

Palavras-chave: Apoptose. FAS/FASL. Células Tipo I e Tipo II. Prostaglandina $E_{2}$. 


\section{ABSTRACT}

Medina LP. Modulation of FAS-mediated death in type I and type II cells [Master thesis (Imunology)]. São Paulo: Instituto de Ciências Biomédicas da Universidade de São Paulo; 2011.

Apoptosis is a cell death process that can be divided didactically into two pathways: the intrinsic and extrinsic pathways. The signaling induced by extrinsic pathway and death receptor-mediated FAS may occur in a mitochondrial dependent or independent manner. In type I cells, the interaction between FAS/FASL directly results in cleavage of caspase- 3 by caspase- 8 , while in type II cells, caspase- 8 cleaves BID, which promotes a mitochondrial amplification for subsequent caspase3 activation. It is important to consider that: 1) Our group's previous results demonstrated that sub-lethal doses of $\mathrm{CHX}$ were able to sensitize type I and type II cells to apoptosis and perform the conversion of type II cells into type I; 2) One of the possible mechanisms involved in this conversion is FAS recruitment to "lipid rafts" (membrane rafts), increasing the signaling efficiency; 3 ) $\mathrm{PGE}_{2}$ can activate PKA by increasing CAMP via EP2 and EP4 receptors, which performs the phosphorylation of Ezrin, a protein involved in FAS recruitment to lipid rafts; 4) $\mathrm{PGE}_{2}$, as well as being able to induce apoptosis in certain cell lines, is able to sensitize others to apoptosis, similar to $\mathrm{CHX}$. Based on these points, we hypothesized that $\mathrm{PGE}_{2}$, due to its sensitizing capacity could, similarly to $\mathrm{CHX}$, sensitize cell lines to apoptosis and perform the conversion of type II cells into type I. The sensitization effect was not observed in DO11.10 cells in which apoptosis was induced by soluble CD95L. In type I and type II cell lines, in which apoptosis was induced by agonist anti-FAS antibody also there was no sensitization effect.

Keywords: Apoptosis. FAS/FASL. Type I and Type II cells. Prostaglandin $E_{2}$. 


\section{LISTA DE ABREVIATURAS E SIGLAS}

A1: BCL-2-related gene A1 / Gene A1 relacionado ao BCL-2

ACAD: Activated T cell autonomous death / Morte autônoma de células T ativadas

AD: Actinomycin D / Actinomicina D

AICD: Activation-induced cell death / Morte celular induzida por ativação

AIDS: Acquired immunodeficiency syndrome / Síndrome da imunodeficiência adquirida

AIF: Apoptosis-inducing factor / Fator indutor de apoptose

ALPS: Autoimmune lympho proliferative syndrome / Síndrome linfoproliferativa autoimune

APAF-1: Apoptotic protease-activating factor 1 / Fator apoptótico de ativação de protease 1

APC: Antigen-presenting cell / Célula apresentadora de antígenos

AraC: Cytosine $\beta-D$ arabinofuranoside

ATP: Adenosine triphosphate / Trifosfato de adenosina

BAD: BCL-2 antagonist of cell death / Antagonista de BCL-2 de morte celular

BAK: BCL-2 antagonist killer 1 / Assassino 1 antagonista de BCL-2

BAX: BCL-2-associated X protein / Proteína X associada ao BCL-2

BCL-2: B-cell CLL/Lymphoma 2 / Linfoma 2 de célula B de leucemia linfóide crônica

BCL-X $\mathbf{X}_{\mathrm{L}}$ : BCL-2-related gene, long isoform / Gene relacionado ao BCL-2, isoforma longa

BH: BCL-2-homology domain / Domínio de homologia ao BCL-2

BID: BH3-interacting domain death agonist / Agonista de morte que interage com o domínio BH3

BIK: BCL-2 interacting killer/ Assassino que interage com BCL-2 
BIM: BCL-2-interacting mediator of cell death / Mediador da morte cellular que interage com BCL-2

BMF: BCL-2 modifying factor/ Fator modificador de BCL-2

CAD: Caspase-activated DNAse / DNAse ativada por caspase

cAMP: Cyclic adenosine monophosphate / Monofosfato de adenosina cíclica

CARD: Caspase-recruitment domain / Domínio de recrutamento de caspase

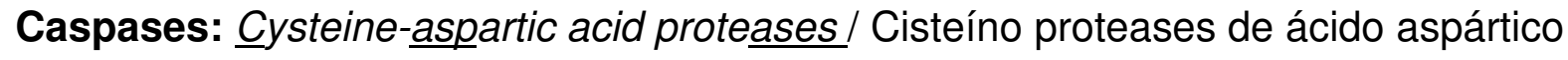

Ced: Cell death abnormal/ Morte celular anormal

C.elegans: Caenorhabditis elegans

c-FLIP: Cellular FLICE-like inhibitory protein / Proteína celular inibitória semelhante a FLICE

CHX: Cycloheximide / Cicloheximida

C-IAP: Cellular-IAP / IAP celular

cox: Cyclooxygenase / Ciclooxigenase

CREB: CAMP responsive element binding factor / Fator de ligação a elementos respondedores a AMPc

Cyt c: Cytochrome c/ Citocromo c

DD: Death domain / Domínio de morte

DED: Death-effector domain / Domínio efetor de morte

DIABLO: Direct IAP-binding protein with low pl / Proteína de ligação direta ao IAP com baixo PI

DISC: Death-inducing signaling complex / Complexo indutor de sinalização de apoptose

DMSO: Dimethyl sulfoxide / Dimetilsulfóxido

DRs: Death receptors / Receptores de morte

EBV: Epstein barr virus / Vírus Epstein barr

ECL: Enhanced chemiluminescence / Quimioluminescência melhorada 
Egl-1: Egg-laying defective / Postura de ovos com defeito

EndoG: Endonuclease G / Endonuclease G

EP: E prostanoid receptor/ Receptor para prostanóide E

EPAC: Exchange protein directly activated by CAMP / Proteína trocadora diretamente ativada por AMPc

ER: Endoplasmic reticulum / Retículo endoplasmático

FACS: Fluorescence-activated cell sorting / Classificação de células ativadas por fluorescência

FADD: FAS-associated death domain / Domínio de morte associado ao FAS

FASL: FAS ligand / FAS ligante

FCS: Fetal calf serum / Soro fetal bovino

FLAG: Fluoresceinated antigen

FSC: Forward scatter/ Dispersão para frente

HEPES: 4-(2-hydroxyethyl)-1-piperazineethanesulfonic acid / 4 - (2-hidroxietil)-1ácido piperazinoetanosulfonico

HFS: Hypotonic fluorescent solution / Solução hipotônica fluorescente

HRK: Harakiri

IAP: Inhibitor of apoptosis proteins / Proteínas inibidoras de apoptose

ICAD: Inhibitor of CAD / Inibidor de CAD

LPS: Lipopolysaccharide / Lipopolissacarídeo

LZ-CD95L: Leucine zipper tagged CD95L / CD95L marcado com leucina zíper

MCL-1: Myeloid cell leukemia 1 / Célula mielóide de leukemia 1

MOMP: Mitochondrial outer membrane permeabilization / Permeabilização da membrana mitocondrial externa

Myd88: Myeloid differentiation primary response gene 88 / Gene de diferenciação mielóide de resposta primária 88

NF-kB: Nuclear factor kappa B / Fator nuclear kappa B 
PARP: Poly (ADP-ribose) polymerase / Poli polimerase (ADP-ribose)

PGE $_{2}$ : Prostaglandin $E_{2}$ / Prostaglandina $\mathrm{E}_{2}$

PGHS: Prostaglandin endoperoxide $H$ synthase / Prostaglandinas endoperoxidases $\mathrm{H}$ sintases

PI: Propidium iodide / lodeto de propídeo

PKA: Phosphokinase A / Fosfoquinase A

PMA: Phorbol 12-myristate 13-acetate / Forbol 12-miristato 13-acetato

PS: Phosphatidylserine / Fosfatidilserina

PUMA: p53 upregulated modulator of apoptosis / Modulador de apoptose por upregulação de p53

RPMI: Roswell Park Memorial Institute

SDS: Sodium dodecyl sulfate / Dodecilsulfato de sódio

SMAC: Second mitochondria-derived activator of caspases / Segundo ativador de caspases derivado da mitocôndria

SSC: Sideward scatter / Dispersão para o lado

tBID: Truncated BID / BID truncado

TCR: $T$ cell receptor / Receptor de células T

TLR4: Toll-like receptor 4 / Receptor semelhante ao Toll 4

TNF-R: Tumor necrosis factor-receptor/ Receptor de fator de necrose tumoral

TRAIL-R: TNF-related apoptosis-inducing ligand-receptor / Receptor do ligante indutor de apoptose relacionado ao TNF

VP-16: Etoposide / Etoposídeo

XIAP: X-chromosome linked IAP / IAP ligada ao cromossomo X 


\section{SUMÁRIO}

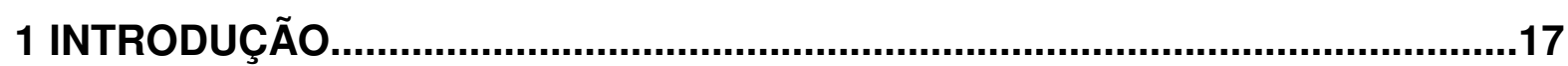

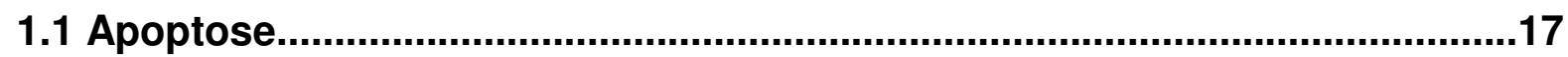

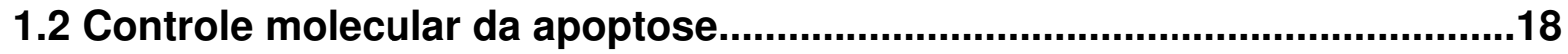

1.3 Células Tipo I versus células Tipo II...............................................................22

1.4 Importância da sinalização via FAS/FASL na homeostasia de LTCD4........25

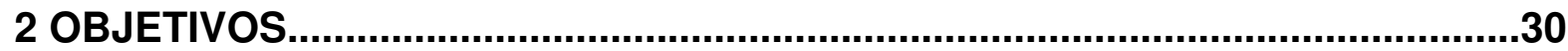

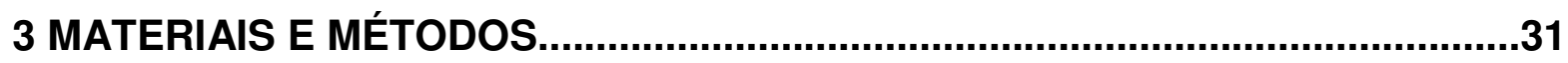

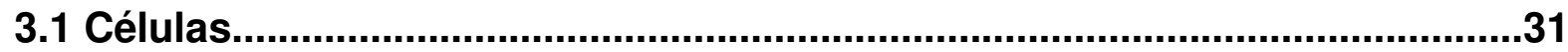

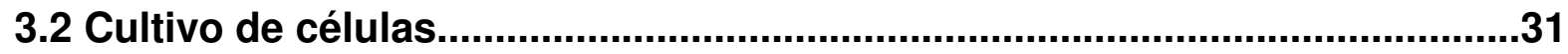

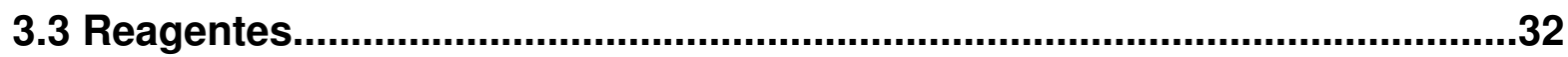

3.4 Análise de apoptose via fragmentação de DNA (HFS)...................................32

3.5 Análise de apoptose por externalização de fosfatidilserina e incorporação

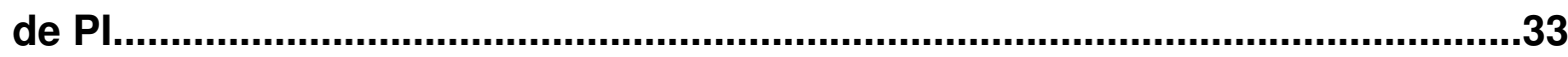

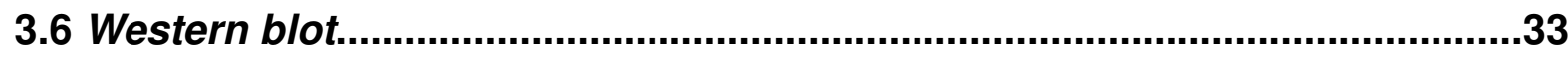

3.7 Estimulação dos hibridomas com anti-CD3..................................................34

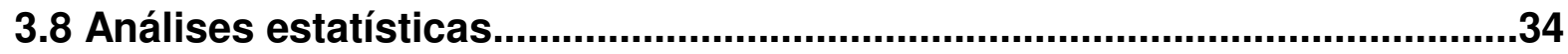

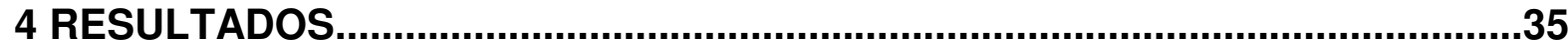

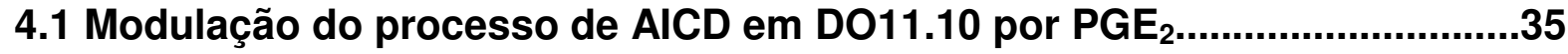

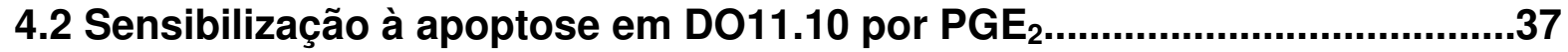

4.3 Caracterização de células Tipo I e Tipo Il.......................................................44

4.4 Sensibilização à apoptose por $\mathrm{PGE}_{2}$ em células Tipo I e Tipo II....................48

5 DISCUSSÃO

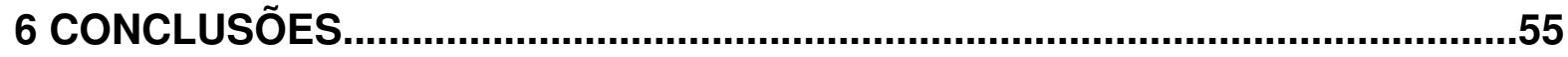

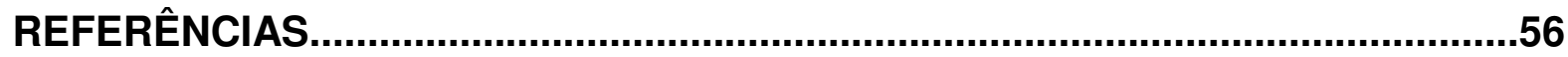




\section{INTRODUÇÃO}

\subsection{Apoptose}

Em organismos pluricelulares, desde a formação do embrião até o indivíduo adulto, há um constante balanço entre proliferação e morte celular, necessário para o perfeito desenvolvimento do organismo. Esse balanço pode ser evidenciado, por exemplo, em uma infecção, na qual ocorre a expansão de populações celulares importantes para uma resposta imune mais eficiente e, após eliminação do patógeno, há a contração dessas populações expandidas, garantindo a homeostase. Além da sua importância em processos infecciosos, a morte celular garante a eliminação de células indesejadas, danificadas, potencialmente autorreativas ou que atingiram o término de sua vida útil. Entretanto, o processo de morte pode ser induzido pelo próprio patógeno como mecanismo de escape, tornando-se nocivo ao organismo. O descontrole da morte, portanto, está implicado com uma variedade de condições patológicas tais como doenças autoimunes e câncer, quando há resistência à morte, ou doenças degenerativas, nos casos de aumento excessivo da mesma (1-3).

Dentre os diferentes tipos de morte celular existentes atualmente, como morte com autofagia, necrose e cornificação, a apoptose (4) é a mais estudada e possui algumas características bem marcantes, tais como formação de pregas na membrana plasmática, retração do citoplasma e consequente diminuição do tamanho da célula, permeabilização mitocondrial, liberação de cyt c (cytochrome c), clivagem do DNA e exposição de PS (phosphatidylserine) na face externa da membrana plasmática (5-7). A exposição da PS é uma das alterações que contribui para que a célula apoptótica seja reconhecida, fagocitada e eliminada, graças à presença de receptores específicos, como TIM-4, na membrana de macrófagos e outros fagócitos (8-10). Dessa forma, a apoptose é classificada como um processo silencioso de morte celular, capaz de manter a integridade do tecido uma vez que não há extravasamento de conteúdo intracelular, como citocinas e enzimas lisossomais, não levando, portanto, ao desencadeamento do processo inflamatório (11-12). 
Estudos realizados no nematódeo C. elegans (Caenorhabditis elegans), pelos pesquisadores Sydney Brenner, John E. Sulston e Robert Horvitz, ganhadores do prêmio Nobel de Medicina em 2002 (13-15), possibilitaram a identificação de um conjunto de genes envolvidos na regulação da apoptose. Nesses organismos foram descritos quatro genes: ced-3, responsável pela execução da morte; ced-4, necessário para ativação do ced-3; ced-9, que impede a apoptose ao inibir ced-4; e egl-1, que induz apoptose ao inibir ced-9 (16-17). Posteriormente, um grupo de genes homólogos aos descritos em $C$. elegans foram identificados em mamíferos: caspases (homólogas a ced-3) (18), APAF-1 (homóloga a ced-4), proteínas antiapoptóticas da família BCL-2 (homólogas a ced9) e proteínas pró-apoptóticas BH3-only da família BCL-2 (homólogas a egl-1). Apesar de a organização ser mais complexa em mamíferos e de haver tantas mais moléculas envolvidas, o mecanismo básico de genes indutores, inibidores e executores de morte continua presente $(17,19)$, sendo a utilização desse nematódeo como modelo experimental, de grande importância na identificação de proteínas que controlam a apoptose em células humanas.

\subsection{Controle molecular da apoptose}

Os processos moleculares da apoptose envolvem duas vias bem estabelecidas, a via intrínseca e a via extrínseca. A via intrínseca (Figura 1) pode ser estimulada por diferentes sinais, tais como irradiação, agentes quimioterápicos, vírus e ausência de fatores de crescimento, os quais geram estresses intracelulares ativando proteínas que vão induzir apoptose diretamente pela via mitocondrial.

A via mitocondrial é regulada por proteínas anti e pró-apoptóticas da família BCL-2 (B-cell CLL/Lymphoma 2), cuja classificação é baseada na função e nos domínios de homologia ao BCL-2 (BH - BCL-2-homology domain). As proteínas antiapoptóticas (BCL-2, BCL-X $\mathrm{L}, \mathrm{BCL}-\mathrm{W}, \mathrm{MCL}-1, \mathrm{~A} 1$ ), localizadas na membrana externa da mitocôndria, no citosol ou na membrana do ER (endoplasmic reticulum), possuem os domínios $\mathrm{BH} 1-\mathrm{BH} 4$ e são responsáveis pelo bloqueio do MOMP (mitochondrial outer membrane permeabilization), que é a permeabilização da membrana externa mitocondrial. As proteínas pró-apoptóticas, por sua vez, são subdivididas em dois outros grupos: o das moléculas efetoras e o das proteínas 
BH3-only. As moléculas efetoras (BAX e BAK), as quais são constantemente inibidas pelas proteínas antiapoptóticas, possuem os domínios $\mathrm{BH} 1-\mathrm{BH} 3$ e são responsáveis pela formação dos poros na membrana externa mitocondrial e conseqüente indução do MOMP, possibilitando a liberação de diversos fatores próapoptóticos (20). As proteínas BH3-only (BID, BIM, BAD, BIK, PUMA, NOXA, BMF e HRK), funcionam como sensores de estresse intracelular e sinais pró-apoptóticos e atuam de duas formas distintas (21-22). Proteínas BH3-only sensibilizadoras ou derepressoras (BAD, BIK, NOXA, PUMA) ligam-se diretamente as proteínas antiapoptóticas liberando BAX e BAK, enquanto que, proteínas BH3-only conhecidas como ativadoras diretas (BID, BIM), podem atuar tanto ligando-se diretamente a BAX e BAK potencializando a ação dessas proteínas quanto neutralizando as proteínas antiapoptóticas (23).

Além da família BCL-2, a família das caspases também desempenha um papel essencial no processo de apoptose. As caspases são cisteíno-proteases, frequentemente presentes na forma de precursores inativos (zimógenos), em células saudáveis, sendo ativadas após estímulos específicos, como por exemplo, irradiação. Até o momento, já foram descritas 14 caspases em mamíferos, dentre as quais 12 estão presentes em humanos $(11,24)$. No processo de apoptose, apenas 7 caspases estão envolvidas e são divididas em caspases iniciadoras e efetoras. As caspases iniciadoras ou apicais $(-2,-8,-9$ e -10) são encontradas na forma de monômeros e são ativadas por homo-dimerização induzida por proximidade. Além da ativação, estas caspases podem passar por um processo de autoclivagem, tornando-se capazes de ativar as caspases efetoras ou executoras (-3, -6 e -7), sendo estas últimas, encontradas na forma de dímeros e sempre ativadas por clivagem proteolítica imediatamente após resíduos de ácido aspártico. É importante ressaltar que as caspases envolvidas no processo de apoptose não são restritas apenas a este fenômeno e participam também de outros processos como proliferação celular (25-26). 


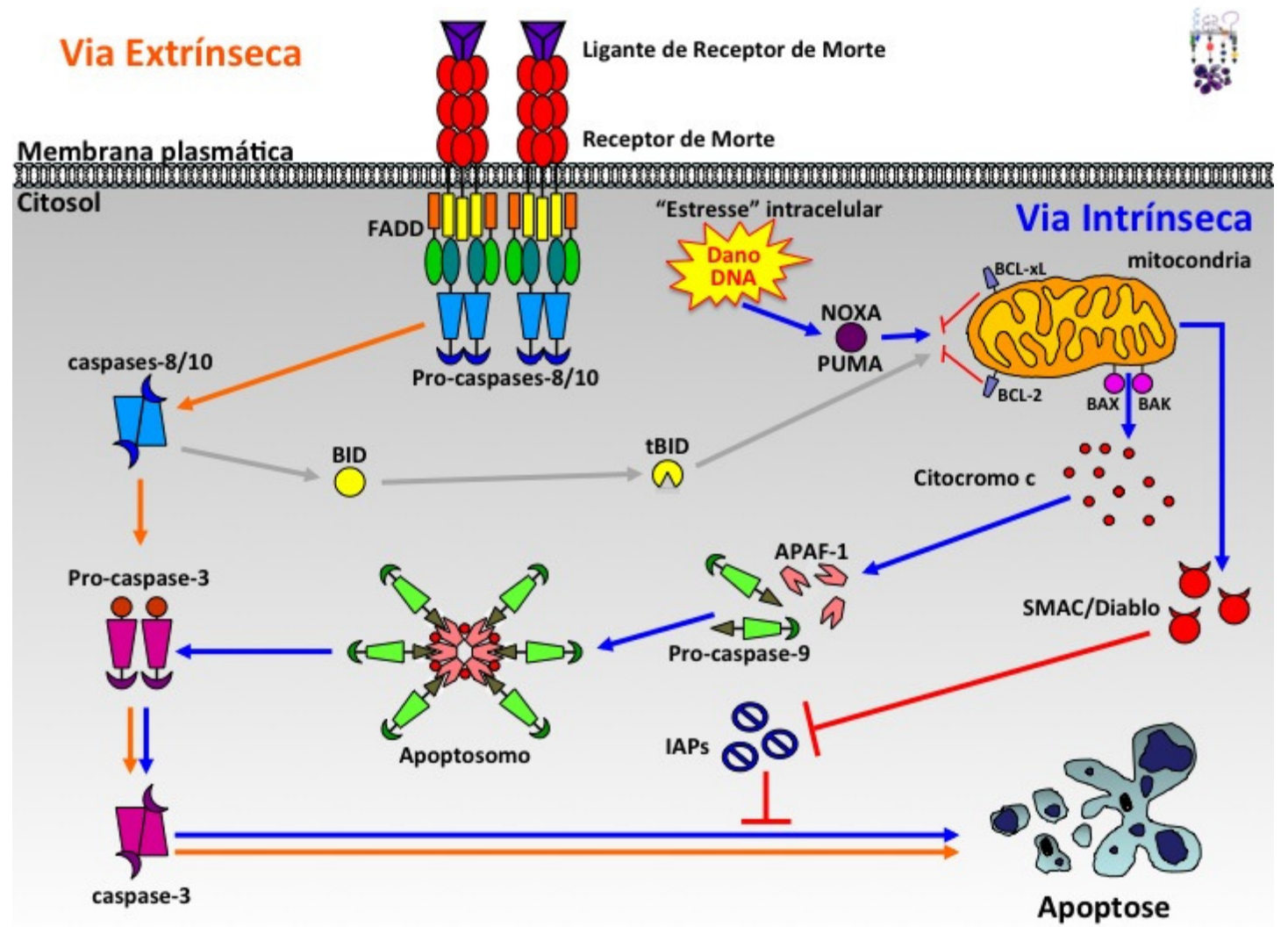

Figura 1. Apoptose. Sinalização do processo de apoptose pela via extrínseca, induzida através da interação entre receptores de morte e seus respectivos ligantes e pela via intrínseca, ativada por estresses intracelulares. Ambas as vias resultam numa via comum de morte, na qual há ativação da caspase-3 que resulta na apoptose. A comunicação com a mitocôndria durante a via extrínseca é realizada pela proteína BID da família BCL-2. Fonte: Adaptado de (27)

Diferentemente da via intrínseca, a via extrínseca (Figura 1) ocorre através da interação de receptores de morte (DRs - death receptors) com seus respectivos ligantes, ou seja, através de sinais externos, e pode ocorrer com ou sem a participação da mitocôndria (28). Os DRs pertencem à família TNFR (tumor necrosis factor receptor), da qual fazem parte FAS, TNF-R1 e TRAIL-R1 e 2 (TNFrelated apoptosis-inducing ligand receptor 1 and 2), cujos respectivos ligantes são FASL (FAS ligand), TNF- $\alpha$ e TRAIL (29-30).

FAS (CD95/APO-1), o protótipo dos receptores de morte, é expresso constitutivamente na maioria dos tecidos celulares e é caracterizado pela presença de um a seis domínios ricos em cisteína em suas porções extracelulares, que são responsáveis pela ligação com FASL (CD95L/APO-1L) (30). A ligação entre trímeros de FAS e FASL resulta no recrutamento de proteínas adaptadoras chamadas FADD (FAS-associated death domain), através da interação entre os 
domínios DD (death domain) presentes tanto nesta molécula quanto no receptor FAS (31). Além disso, há o recrutamento de pró-caspase-8 que interage com FADD através de outro domínio, DED (death-effector domain) (32), formando um complexo que é denominado de DISC (death-inducing signaling complex). Este complexo resulta na ativação e autoclivagem da caspase-8 (33) e é, posteriormente, internalizado prosseguindo com a cascata de sinalização intracelular (34). Foi descrito que caspase-10 também é capaz de se associar ao FADD no complexo DISC, sendo a única, além da caspase-8, a possuir o domínio DED (35).

Há, ainda, outra proteína capaz de participar do complexo DISC, denominada de c-FLIP (cellular FLICE-like inhibitory protein). Dentre as três isoformas

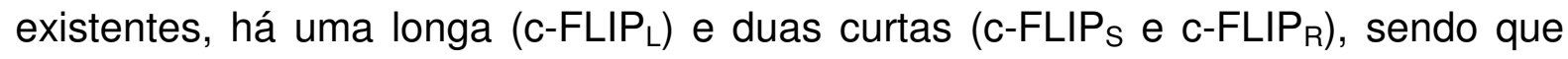
todas apresentam um domínio DED muito semelhante ao domínio DED da caspase8, competindo com esta por uma ligação ao FADD e inibindo o processo de apoptose. Entretanto, C-FLIPL possui ainda outro domínio, homólogo ao domínio catalítico da caspase-8 e embora esse domínio seja cataliticamente inativo (36), acredita-se que a associação de c-FLIPL ao complexo DISC possa atuar estimulando a apoptose ou até redirecionar sinais de morte rumo às vias de sobrevida e proliferação, o que parece estar diretamente relacionado com a concentração desta isoforma da proteína na célula (26, 37-39).

Marcus E. Peter e colaboradores mostraram, em 2010, que a sinalização via FAS pode estar implicada não somente com o processo de apoptose, como também com o crescimento e a proliferação celular, dados que corroboram com os achados da proteína c-FLIP (37, 40-41). Tais funções parecem estar relacionadas com níveis basais de FAS/FASL, uma vez que a redução destas moléculas leva a uma diminuição de massa tumoral em ensaios realizados com câncer de ovário, enquanto que o aumento das mesmas não foi capaz de causar nenhuma alteração perceptível. Além disso, foi demonstrado que a concentração de FAS necessária para induzir apoptose é mil vezes maior do que para induzir sinais não-apoptóticos. A participação de FAS também foi observada no processo de regeneração hepática, mostrando que em uma hepatectomia parcial não há a completa recuperação do órgão na ausência do receptor, sugerindo uma possível ligação entre FAS e o desenvolvimento de hepatocarcinogênese (42). 


\subsection{Células Tipo I versus Células Tipo II}

A sinalização induzida pela via extrínseca e mediada pelo receptor FAS pode ocorrer de forma dependente ou independente da mitocôndria, caracterizando dois tipos distintos de células. Quando a formação do DISC resulta na ativação direta de caspase-3 pela caspase-8, sem a participação da mitocôndria, estas células são denominadas de Tipo I. Por outro lado, quando a formação desse complexo não é suficiente para ativar diretamente caspase-3, sendo necessária uma amplificação mitocondrial, estas células são chamadas de Tipo II.

Assim, em células Tipo II, após a formação do DISC, caspase-8 cliva BID (BH3-interacting domain death agonist) em seu domínio $\mathrm{BH} 3$ e gera o fragmento tBID (truncated BID) (43-44). Este fragmento é transferido para a mitocôndria onde colabora com a agregação de BAX (BCL-2-associated $X$ protein) e BAK (BCL-2 antagonist killer 1) que realizam a formação dos poros na membrana externa da organela, permitindo a liberação de determinados fatores do espaço intermembrana para o citosol (20). Dentre esses fatores, o de maior importância no contexto apoptótico é o cyt c (45), que após ser liberado, se associa a uma molécula de ATP (adenosine triphosphate) e a uma proteína adaptadora chamada de APAF-1 (apoptotic protease-activating factor 1). APAF-1, por sua vez, sofre uma mudança conformacional e se liga à pró-caspase-9 através do domínio CARD (caspaserecruitment domain), formando um importante complexo protéico denominado de apoptossomo, o qual permite a autoclivagem da pró-caspase-9 (46). A caspase-9 agora cliva e ativa pró-caspase-3 e esta ativação, seja indiretamente por caspase- 9 no apoptossomo (células Tipo II) ou diretamente pela caspase-8 no DISC (células Tipo I) ambos os tipos celulares comportam-se da mesma forma (47). Caspase-3 ativada cliva diversos substratos, os quais serão responsáveis pelas alterações características de uma célula apoptótica. Dentre esses substratos pode-se destacar: ICAD (inhibitor of CAD), que depois de clivado libera CAD (caspase-activated $D$ Nase) que, por sua vez, é translocado para o núcleo onde realiza a clivagem do DNA nos espaços internucleossomais (48); e a enzima PARP (poly(ADP-ribose) polymerase), um substrato típico da caspase-3, responsável pelo reparo de DNA, que perde sua função após clivagem (49). 
A formação dos poros na mitocôndria causada pela agregação de BAX e BAK resulta não só na liberação de cyt c, como também de outros fatores envolvidos no processo de morte celular. SMAC/DIABLO (50-51) e OMI/HTRA2 são responsáveis por antagonizar os IAPs (inhibitor of apoptosis proteins), uma família de inibidores, tais como XIAP (X-chromosome linked IAP), C-IAP1 e c-IAP2 (cellular $(A P)$, que se associam as caspases recentemente ativadas no citosol. AIF (apoptosis-inducing factor) e EndoG (endonuclease G) (52) translocam-se para o núcleo e cooperam diretamente com a clivagem do DNA, onde atuam dependente ou independentemente de caspases (53-55).

Alguns trabalhos $(44,56)$ demonstraram, através de ensaios de morte, que células que dependem da mitocôndria para amplificar o sinal de morte, tornam-se resistentes à apoptose pela superexpressão de BCL-2, proteína capaz de inibir BID quando este é clivado, ativado e transferido para a mitocôndria. Também foi demonstrado que outras proteínas antiapoptóticas da família BCL-2, como BCL- $X_{L}$ (BCL-2-related gene, long isoform), são capazes de inibir a via mitocondrial (57-58). O grupo do Dr. Stanley Korsmeyer demonstrou, em 1995, que um bcl- $x_{L}$ transgene foi capaz de substituir a presença do bcl-2 em linfócitos de camundongos deficientes sem apresentar qualquer prejuízo $(11,59)$.

Em contrapartida, esta resistência a apoptose não ocorre em células Tipo I, uma vez que apresentam um mecanismo direto de ativação de caspase-3, sem participação da mitocôndria, em que a superexpressão de BCL-2 não é capaz de inibir o processo de apoptose. Dentre os modelos utilizados para confirmar tal idéia, vale ressaltar que em células SKW.6.4 (Tipo I), a superexpressão de BCL-2, mesmo em maiores quantidades, não resultou em nenhuma alteração na sensibilidade à apoptose. Já em células Jurkat (Tipo II) a superexpressão por BCL-2, em quantidades menores, resultou em uma significativa resistência à apoptose. Dados previamente publicados apóiam a ideia de que ambas as células utilizam a via mitocondrial para induzir apoptose, porém apenas células Tipo II dependem exclusivamente dessa via para morrer (44).

Vale ressaltar, ainda, que esses dois "tipos" de células não foram observados apenas in vitro, mas também identificados in vivo (60). Em um estado fisiológico as células $\beta$-pancreáticas (61) e as células hepáticas (62) se comportam como células Tipo $\mathrm{II}_{2}$ enquanto todas as demais como Tipo I (63). Entretanto, quando uma 
determinada célula Tipo I passa por um processo de transformação tumoral pode passar a comportar-se como Tipo II, embora o mecanismo envolvido nessa conversão ainda não esteja completamente estabelecido (44). Além disso, há trabalhos na literatura que associam essa transformação tumoral com o aumento da expressão de BCL-2, o que tornaria essas células resistentes a morte induzida tanto via extrínseca quanto via intrínseca, favorecendo a progressão tumoral (64-66). Com base nesses dados, entender o mecanismo envolvido nessa conversão de uma célula para outra, seria importante tanto do ponto de vista fisiológico, uma vez que isso ocorre naturalmente in vivo, quanto do ponto de vista patológico, a fim de encontrar formas de modular essa morte, tornando as células tumorais novamente sensíveis a apoptose e favorecendo uma resposta imunológica frente ao tumor e uma possibilidade de novas drogas terapêuticas.

Dados previamente publicados pelo nosso grupo (67) demonstraram que dose subletal de $\mathrm{CHX}$ (cycloheximide), um inibidor de síntese protéica, capaz de sensibilizar linhagens celulares ao processo de apoptose, foi capaz de converter células Tipo II em Tipo I, ultrapassando os efeitos antiapoptóticos do BCL-2. Assim, após tratamento com $\mathrm{CHX}$, células Tipo II superexpressas por BCL-2, que eram resistentes a apoptose induzida via FAS, tornaram-se tão ou mais sensíveis àquelas que apresentavam quantidades basais de BCL-2, convertendo células Tipo II em células Tipo I. O mecanismo exato envolvido nessa conversão ainda não foi esclarecido, mas há algumas possíveis explicações.

É possível que a caspase-8 tenha maior afinidade por BID, clivando preferencialmente esta molécula em vez de caspase-3 em células Tipo II, talvez pela menor disponibilidade de caspase-8 ou pela maior oferta de BID (44). Com respeito a isso, dados do artigo demonstraram que a $\mathrm{CHX}$ foi capaz de causar uma significativa diminuição do mRNA de BID associado a um desaparecimento total da proteína. Dessa forma, sem a presença de BID, a caspase-8 seria obrigada a clivar diretamente a caspase- 3 , independente da mitocôndria, comportando-se como uma célula Tipo I (67).

Outra possibilidade é que células Tipo II apresentam uma quantidade maior de XIAP que estaria inibindo as caspases recentemente ativadas no citosol. E, apesar dos resultados previamente obtidos pelo nosso grupo terem demonstrado que o tratamento com $\mathrm{CHX}$ não foi capaz de alterar a expressão desta molécula, 
outro trabalho recentemente publicado (68) encontrou uma diferença significante na expressão de XIAP entre células Tipo I e Tipo II.

Mais uma possível explicação para essa conversão seria o recrutamento da molécula FAS para as balsas lipídicas em células Tipo II (69). Estas balsas ou também chamados microdomínios lipídicos são estruturas diferenciadas da bicamada lipídica pela alta concentração de colesterol e esfingolipídios. São especializados em aprimorar a eficiência de algumas sinalizações, como do FAS, uma vez que aproximam e concentram diversas moléculas e adaptadores necessários para a transdução do sinal (70). Está descrito na literatura que FAS está presente nas balsas lipídicas em células Tipo I, mas não em células Tipo II, uma provável explicação para a diferença encontrada na sinalização de morte entre essas células. Assim, em células Tipo I a apoptose é induzida com mais eficiência gerando uma maior quantidade de caspase-8 suficiente para clivar diretamente caspase-3, não necessitando de uma amplificação por sinais mitocondriais (71-72).

\subsection{Importância da sinalização via FAS/FASL na homeostasia de LTCD4}

Os linfócitos TCD4 ${ }^{+}\left(\mathrm{LTCD}^{+}\right)$desempenham um papel central na resposta imunológica, uma vez que através de diferentes sinais são capazes de controlar a ação de outras células, aumentando o desempenho destas e permitindo a formação de uma resposta imune mais efetiva, e é por esta razão que são frequentemente chamados de $\mathrm{T}$ helper ou $\mathrm{T}$ auxiliares (73-74). Durante o desenvolvimento linfocitário é importante que haja um constante balanço entre proliferação e morte celular (apoptose). Quando há uma quebra nessa homeostasia com conseqüente redução significativa desta morte em LTCD4 pode ocorrer linfoacumulação e geração de doenças autoimunes, o que pode ser visto em síndromes como o ALPS (Autoimmune lympho proliferative syndrome), decorrentes de mutações, por exemplo, no gene FAS (ALPS tipo I) ou na caspase 10 (ALPS tipo II) (75-76). Além disso, camundongos knockouts para FAS (lpr) e/ou para FASL (gld) também apresentam problemas de linfoacumulação e autoimunidade pela sinalização via FAS/FASL não estar funcional (77). Por outro lado, o aumento excessivo da apoptose, observada em síndromes como a AIDS (Acquired immunodeficiency 
syndrome), resulta em um estado de imunodeficiência que torna o indivíduo susceptível a muitas infecções oportunistas (78).

É importante levar em consideração que, em linfócitos, o processo de apoptose pode ser desencadeado por dois mecanismos: ACAD (activated T cell autonomous death) e AICD (activation-induced cell death). Ambos são induzidos por ativação, porém a AICD depende de uma re-estimulação do complexo TCR/CD3 enquanto a ACAD não (79). Quando há uma resposta imunológica a um determinado patógeno, sinais dados a partir do complexo TCR ( $T$ cell receptor), de co-estimuladores e de fatores de crescimento estimulam a expressão de proteínas antiapoptóticas da família BCL-2 e essas proteínas promovem sobrevida e subsequente proliferação celular. Porém, com o encerramento da resposta há uma diminuição dos fatores de crescimento e a proteína BIM (BCL-2-interacting mediator of cell death) é ativada, ativando outras proteínas efetoras e desencadeando o processo de ACAD. Isso geralmente ocorre em infecções agudas (80-81).

Por outro lado, durante as infecções crônicas, a constante re-estimulação do complexo TCR/CD3 leva a redução dos níveis de c-FLIP associada ao aumento dos níveis de FASL favorecendo o desencadeamento da AICD (79, 82-83). Inicialmente descrito em hibridomas de linfócitos T e, posteriormente, em linfócitos maduros préativados e demais linfócitos T, a AICD pode ocorrer de forma autócrina, ou seja, quando FASL interage com FAS na mesma célula ou de forma parácrina, quando FASL interage com FAS na superfície de outra célula (84).

Resultados prévios obtidos pelo nosso grupo de pesquisa (85) demonstraram que fatores solúveis liberados no sobrenadante de APCs (antigen-presenting cells) estimuladas por LPS (lipopolysaccharide) através de TLR4 (toll-like receptor 4) via MyD88 (myeloid differentiation primary response gene 88), foram capazes de proteger linfócitos $T$ do processo de AICD. Dentre os fatores liberados, foi observado que a $\mathrm{PGE}_{2}$ (prostaglandin $E_{2}$ ), por si só, já foi capaz de inibir significativamente esse processo. Tal modulação, consistente com outros dados da literatura $(82,86-87)$, ocorre devido à diminuição da expressão de FASL.

A $\mathrm{PGE}_{2}$ é um importante mediador lipídico, liberado de forma basal em condições normais no organismo, participando de alguns processos homeostáticos, tais como manutenção da integridade da mucosa gástrica e da pressão sanguínea (88-89), sendo liberado em grandes quantidades durante uma resposta 
imunológica. O metabolismo das prostaglandinas, liberadas por muitas células do corpo incluindo fibroblastos e macrófagos, tem início com a liberação do ácido araquidônico na quebra de fosfolipídeos da membrana plasmática pela ação da enzima fosfolipase $\mathrm{A} 2 \mathrm{em}$ resposta a estímulos inflamatórios. $\mathrm{O}$ ácido araquidônico é, então, metabolizado por uma enzima chamada de COX (cyclooxygenase) que apresenta duas isoformas COX-1 e COX-2 também denominadas PGHS-1 e PGHS2 (Prostaglandin endoperoxidase $H$ synthase). PGHS-1 é expressa constitutivamente na maioria dos tecidos e está geralmente relacionada à produção basal de prostaglandinas em resposta a estímulos hormonais, enquanto PGHS-2 é induzida e seus produtos estão envolvidos em processos de estresses fisiológicos e infecção/inflamação. O metabolismo do ácido araquidônico resulta na produção de $\mathrm{PGH}_{2}$, uma prostaglandina altamente instável e rapidamente metabolizada por enzimas específicas que dão origem as cinco principais classes de prostaglandinas: $\mathrm{PGl}_{2}, \mathrm{PGF}_{2} \mathrm{\alpha}, \mathrm{PGD}_{2}, \mathrm{TXA}_{2}$ e $P \mathrm{PGE}_{2}$ (90-91).

As prostaglandinas recém produzidas são rapidamente liberadas e atuam nas células próximas ao seu local de origem, através do seu reconhecimento por receptores específicos presentes nas membranas plasmáticas das mesmas. A $\mathrm{PGE}_{2}$, por exemplo, exerce suas atividades através da ligação a um ou a uma combinação de 4 subtipos de receptores (EP1-EP4 - E prostanoid receptor). Estes receptores estão acoplados a diferentes proteínas $\mathrm{G}$, o que explica, em parte, a ação da $\mathrm{PGE}_{2}$ no sistema imune ser tão complexa e possuir tantos efeitos antagônicos, tendo ação, por exemplo, tanto anti quanto pró-apoptótica (89). Os receptores EP2 e EP4, acoplados a proteína Gs, levam a ativação da adenilato ciclase, uma enzima transmembrana que catalisa a conversão de ATP em cAMP (cyclic adenosine monophosphate), e resulta, geralmente, na ativação da PKA (phosphokinase $A$ ), a qual ativa o fator de transcrição CREB (cAMP responsive element binding factor) (92-93). Recentemente, foi descrita uma nova via dependente de CAMP, porém independente de PKA, mediada pelo EPAC (exchange protein directly activated by $c A M P$ ) que culmina na ativação da via de PKB. Em contraste, os receptores EP1 e EP3, acoplados a proteínas Gq e Gi, elevam os níveis de cálcio intracelular e inibem o aumento de cAMP, respectivamente (94). Dados da literatura mostram uma ampla distribuição desses 
quatro receptores em células do sistema imunológico, tanto em macrófagos e células dendríticas, quanto em linfócitos T e B (95-96).

Dentre os dados publicados pelo nosso grupo (85) foi demonstrado que a $\mathrm{PGE}_{2}$ atua reduzindo os níveis de FASL através do seu reconhecimento pelos receptores EP2 e EP4 presentes nos linfócitos. A importância desses fatos poderia explicar a capacidade das APCs em adiarem a morte de linfócitos T ativados durante as infecções, até que haja eliminação completa do patógeno, garantindo respostas imunes mais eficientes. Por outro lado, isso poderia permitir a morte de linfócitos quando estes são ativados por antígenos próprios.

Há diversos trabalhos na literatura demonstrando que a $\mathrm{PGE}_{2}$ é capaz de induzir a expressão de FASL em linhagens de câncer de cólon através do seu reconhecimento pelo receptor EP1. Dados revelam que este receptor está aumentado em muitos tipos de cânceres em comparação a tecidos normais e este aumento está relacionado a uma maior progressão do tumor (97-98). Por outro lado, também foi demonstrado que a $\mathrm{PGE}_{2}$ é capaz de bloquear a indução de FASL e inibir o processo de AICD e a citotoxicidade celular mediada por FAS. Estes efeitos ocorrem devido ao aumento de cAMP e consequente inibição de fatores de transcrição responsáveis pela expressão de FASL, como o NF- $\square \mathrm{B}$ (nuclear factor kappa B) (86, 99). Corroborando com esses achados, dados previamente publicados pelo nosso grupo (85) demonstraram que a $\mathrm{PGE}_{2}$, via reconhecimento pelos receptores EP2 e EP4, ou seja, via aumento de cAMP, foi capaz de proteger linfócitos $T$ do processo de AICD através da modulação dos níveis de FASL. Entretanto, o mecanismo exato pelo qual o cAMP modula o FASL ainda não foi elucidado.

Se por um lado existem diversos trabalhos na literatura sobre o papel da $\mathrm{PGE}_{2}$ na modulação da proteína FASL, por outro, praticamente não há relatos sobre a ação dessa molécula na modulação direta do receptor FAS, evidenciando a grande importância de uma investigação mais aprofundada nessa área. Um dos únicos trabalhos que aborda esse assunto (100) demonstrou que a PGE 2 foi capaz de induzir apoptose em fibroblastos de pulmão. Essa função pró-apoptótica também foi mediada pelos receptores EP2 e EP4, ou seja, pelo aumento de cAMP. Diversos fatores parecem estar relacionados com esse efeito, sendo que um deles é o aumento da expressão do receptor FAS. De fato, resultados preliminares do nosso 
grupo demonstraram que a $P G E_{2}$ foi capaz de causar uma sensibilização dos hibridomas de linfócitos T DO11.10 à morte quando esta foi estimulada diretamente via FAS por um anticorpo agonista (101). Foi especulado que essa sensibilização poderia ocorrer devido ao recrutamento do receptor FAS para as balsas lipídicas. Linfócitos $\mathrm{T} \mathrm{CD4}^{+}$ativados são considerados células Tipo II e, por isso, possuem a maior parte das moléculas de FAS ausente nas balsas lipídicas (102). Dentre os diversos mecanismos que levam ao recrutamento de moléculas para esses microdomínios lipídicos, podemos citar a fosforilação da ezrina, uma proteína associada ao citoesqueleto de actina, pela PKA ou pela PKC (103). Uma vez que a $\mathrm{PGE}_{2}$ pode levar a ativação de PKA através do aumento de cAMP (92), é possível que esta molécula sensibilize os linfócitos $T$ ao processo de apoptose pelo recrutamento de FAS para os membrane rafts (104).

Com base nos seguintes dados: 1) Doses subletais de $\mathrm{CHX}$ foram capazes de sensibilizar linhagens celulares Tipo I e Tipo II ao processo de apoptose e realizar a conversão de células Tipo II em Tipo I; 2) Um dos possíveis mecanismos envolvidos nessa conversão seria o recrutamento da molécula FAS para os membrane rafts; 3) $\mathrm{A} \mathrm{PGE}_{2}$ pode ativar PKA resultando na fosforilação da ezrina e no recrutamento do receptor para os microdomínios lipídicos; 4) $A P E_{2}$ além de ser capaz de induzir apoptose em determinadas linhagens celulares, foi capaz de sensibilizar outras ao processo de apoptose, de forma semelhante a $\mathrm{CHX}$ Formulamos a hipótese de que a $\mathrm{PGE}_{2}$ poderia, de forma semelhante a $\mathrm{CHX}$, sensibilizar linhagens celulares Tipo I e Tipo II ao processo de apoptose e se essa sensibilizacão poderia resultar na conversão de células Tipo II em Tipo l. 


\section{OBJETIVOS}

- Comprovar a capacidade da $\mathrm{PGE}_{2}$ em sensibilizar hibridomas de linfócitos T DO11.10 e de outras células ao processo de apoptose mediado pelo receptor de morte FAS;

- Avaliar a capacidade da $\mathrm{PGE}_{2}$ em realizar a conversão de células Tipo II em Tipo I, ultrapassando os efeitos antiapoptóticos da proteína BCL-2 e/ou BCL$X_{L}$. 


\section{MATERIAIS E MÉTODOS}

\subsection{Células}

As linhagens celulares de linfoblasto $T$, derivadas de leucemia linfoblástica aguda, CEM e CEM.BCL-2, e de linfócitos $B$, derivadas de células transformadas pelo EBV (Epstein barr virus), SKW.6.4 e SKW.6.4.BCL-2, foram gentilmente cedidas pelo Dr. Henning Walczak (German Cancer Research Center, Heidelberg, Germany). As linhagens celulares de pró-mielócitos, derivadas de leucemia mielóide aguda, HL-60 e HL-60.BCL-2, foram previamente identificadas pelo nosso grupo (57), enquanto $\mathrm{HL}-60 . B C L-X_{L}$ foi gentilmente cedida pelo laboratório do Dr. Kapil Bhalla (Câncer Center, Medical College of Geórgia). O hibridoma DO11.10, originalmente cedido pelo Dr. Douglas Green (La Jolla Institute for Allergy \& Immunology, San Diego, CA, EUA), foi obtido pela fusão entre linfócitos TCD4+ extraídos de camundongos BALB/c Tg (DO11.10)10Loh com TCR transgênico para o peptídeo 323-339 da ovalbumina apresentado em um contexto de MHC classe II IAd e células de timoma nocautes para o TCR $\beta^{-1-}$ denominada de células BW5147. As células foram selecionadas para a alta produção de IL-2 quando estimuladas pelo complexo $\mathrm{MHC}+$ antígeno ou concavalina $\mathrm{A}$ e posteriormente descritas como células sensíveis a AICD induzida por CD3 ou pela combinação de PMA (phorbol 12-myristate 13-acetate) e ionomicina. A grande vantagem deste modelo é que a AICD nestas células ocorre já ao primeiro estímulo, não necessitando de um estímulo prévio e descanso por alguns dias (105-106).

\subsection{Cultivo de Células}

Todas as linhagens celulares utilizadas neste trabalho foram mantidas em meio de cultura RPMI-1640 (Roswell Park Memorial Institute) suplementado com 25 mM HEPES (4-(2-hydroxyethyl)-1-piperazineethanesulfonic acid), 10\% de FCS (fetal calf serum), $2 \mathrm{mM}$ de L-glutamina e antibióticos $(100 \mathrm{U} / \mathrm{mL}$ de penicilina e 100 $\mu \mathrm{g} / \mathrm{mL}$ de estreptomicina). Estas células foram armazenadas em estufa a $37^{\circ} \mathrm{C}$ em $5 \%$ de $\mathrm{CO}_{2}$. O uso das células para experimentos foi condicionado ao mínimo de $95 \%$ de viabilidade verificada por exclusão com Azul de Tripan $0,2 \%$. A contagem 
do número de células tanto para repique quanto para a execução dos experimentos foi realizada com o auxílio de uma câmara de Neubauer.

\subsection{Reagentes}

Os anticorpos primários utilizados no Western Blot foram: Anti-BCL-2 monoclonal (clone 100, Santa Cruz, Carpinteria, CA, USA), anti-BCL-X monoclonal (clone 2H12, Biosource International) e anti- $\beta$-actina monoclonal (clone AC-15, Sigma Chemical $\mathrm{Ca}$, St. Louis, MO, USA). Os anticorpos anti-EP1 a EP4 foram adquiridos da Cayman Chemicals Co. (Ann Arbor, MI, EUA). Os anticorpos secundários foram: anti-mouse (clone NA93IV, GE Healthcare) e mouse anti-rabbit (SA6-1D10, Jackson Immuno Research). O anticorpo agonista anti-FAS (clone $\mathrm{CH} 11$ - Upstate) foi adquirido da Millipore, enquanto o anticorpo recombinante CD95L solúvel foi gentilmente cedido pelo Dr. Henning Walczak (Faculty of Medicine, Imperial College London, UK). O CD3 (clone 2C11) derivado do hibridoma 145-2C11 (106) foi produzido e purificado em nosso laboratório.

As drogas utilizadas foram: $\mathrm{CHX}$, preparada numa solução estoque de 888 mM em etanol, VP-16 (etoposide), solução estoque de 100 mM em DMSO (dimethyl sulfoxide), AraC (cytosine $\beta$-D-arabinofuranoside) em solução estoque de $100 \mathrm{mM}$ em $\mathrm{H}_{2}$ Odd e $\mathrm{AD}$ (actinomycin $D$ ), solução estoque de $1 \mathrm{mg} / \mathrm{mL}$ em DMSO, adquiridos da Sigma Chemical Ca (St. Louis, MO, USA). A PGE 2 foi adquirida da Cayman Chemicals Co. (Ann Arbor, MI, EUA), enquanto a forskolina foi comprada da Sigma-Aldrich (St. Louis, MO, EUA).

\subsection{Análise de apoptose via fragmentação de DNA (HFS)}

Duzentas mil células $\left(2 \times 10^{5}\right)$ de cada poço de cultura, derivadas dos ensaios de morte realizados, foram centrifugadas a $300 \mathrm{xg}$ por $5 \mathrm{~min}$ a $4{ }^{\circ} \mathrm{C}$ e ressuspendido em $400 \mu \mathrm{L}$ de tampão HFS (hypotonic fluorescent solution) [0,1\% de Triton X-100, $0,1 \%$ de citrato de sódio e $50 \mu \mathrm{g} / \mathrm{mL}$ de PI (propidium iodide)]. Os ensaios foram analisados por citometria de fluxo no citômetro FACS (fluorescence-activated cell sorting) Calibur (Becton Dickinson, Mountain View, CA, USA). Foram considerados eventos apoptóticos os núcleos hipodiplóides, que no gráfico aparecem à esquerda 
do pico G0-G1. Foram analisados 5000 eventos, em triplicata, e o gate das populações a serem avaliadas foi delineado utilizando-se os parâmetros de tamanho (FSC - forward scatter) e granulosidade (SSC - sideward scatter), excluindo os debris da análise.

\subsection{Análise de apoptose por externalização de resíduos de fosfatidilserina e incorporação de PI}

Após a realização dos ensaios de morte, $2 \times 10^{5}$ células foram centrifugadas a $300 \mathrm{xg}$ por 5 min e lavadas uma vez em tampão HEPES [10 mM HEPES, 150 mM $\mathrm{NaCl}, 5 \mathrm{mM} \mathrm{KCl}, 1 \mathrm{mM} \mathrm{MgCl}$ e 1,8 $\mathrm{mM} \mathrm{CaCl}$ ]. Em seguida, as células foram ressuspendidas em $100 \mu \mathrm{L}$ de tampão HEPES, contendo a quantidade apropriada de anexina V-FITC e incubadas por 20 min no escuro a TA (temperatura ambiente). Após esse período, foram acrescentados $350 \mu \mathrm{L}$ de tampão HEPES e $50 \mu \mathrm{L}$ de uma solução de PI a $100 \mu \mathrm{g} / \mathrm{mL}$ em tampão HEPES e a análise por citometria de fluxo foi realizada imediatamente.

\subsection{Western-blot}

Para a preparação dos lisados protéicos, uma alíquota da ordem de $10^{6}$ células de cada amostra foi centrifugada a $240 \mathrm{xg}$ por $5 \mathrm{~min}$ e o sedimento celular foi solubilizado em $100 \mu \mathrm{L}$ de tampão de amostra 1X [50 mM Tris-HCl, pH 6,8; 2\% SDS, $10 \%$ glicerol e $2,5 \%$ de $\beta$-mercaptoetanol]. As amostras foram aquecidas a $100{ }^{\circ} \mathrm{C}$ por $5 \mathrm{~min}$, resfriadas no gelo por $1 \mathrm{~min}$ e estocadas a $-20{ }^{\circ} \mathrm{C}$. Após a aplicação em gel de poliacrilamida a $12 \%$, os lisados foram submetidos à carga elétrica de 80-100 V por 2 h 30 min para a realização da eletroforese. Depois, as proteínas do gel foram transferidas para uma membrana de PVDF (Millipore Corporation, Billerica, Massachusetts) através de um sistema de transferência semiseco a $15 \mathrm{~V}$ por 50 min (Semi-dry transfer cell - BIO-RAD). A membrana foi bloqueada com uma solução de $5 \%$ leite em TBS-Tween (leite em pó desnatado Molico/Nestlé) overnight na geladeira ou $3 \mathrm{~h}$ em agitação a TA. Após o bloqueio, a membrana foi incubada overnight na geladeira com o anticorpo primário, lavada 3 vezes de 15 min com TBS Tween, incubada com o anticorpo secundário por $1 \mathrm{~h} \mathrm{a}$ 
TA e por fim, lavada novamente 3 vezes de $15 \mathrm{~min}$. A detecção dos imunocomplexos foi realizada pelo método de quimiluminescência realizado através da exposição da membrana ao ECL (enhanced chemiluminescence), preparado em nosso laboratório [Solução A: $9 \mathrm{~mL} \mathrm{H} \mathrm{H}_{2} \mathrm{O}, 1 \mathrm{~mL}$ Tris/HCL $1 \mathrm{M} \mathrm{pH} 8.5,22 \mu \mathrm{L} p$ Coumaric acid 90 mM, $50 \mu \mathrm{L}$ Luminol 250 mM e Solução B: $900 \mu \mathrm{L} \mathrm{H}_{2} \mathrm{O}$ e $100 \mu \mathrm{L}$ $\mathrm{H}_{2} \mathrm{O}_{2} 30 \%$ ] com posterior exposição das membranas a um filme de autorradiografia. Os filmes foram escaneados e digitalizados pelo software HP PrecisionScan LTX (Epson Co.).

\subsection{Estimulação dos hibridomas com CD3}

Antes da exposição das células ao CD3 é preciso imobilizá-lo na placa de cultura. Para tanto, este foi diluído em tampão de CD3 [Tris $50 \mathrm{mM} \mathrm{pH} \mathrm{9,0]} \mathrm{na}$ concentração de $1 \mu \mathrm{g} / \mathrm{mL}$ e $100 \mu \mathrm{L}$ dessa solução foram plaqueados em uma placa de 96 poços de fundo reto. A placa foi incubada por $2 \mathrm{~h}$ a $37^{\circ} \mathrm{C}$ em estufa ou overnight a $4{ }^{\circ} \mathrm{C}$ na geladeira. Após esse período, a solução de CD3 foi descartada e $2 \times 10^{5}$ células foram plaqueadas em um volume final de $100 \mu \mathrm{L}$ e incubadas overnight em estufa.

\subsection{Análises Estatísticas}

As análises estatísticas foram realizadas com o auxílio de um software computacional chamado Graphpad Prism da companhia Graphpad Software Incorporation, versão 5. Foi realizado o teste ANOVA, seguido pelo teste Tukey. O primeiro tipo de análise foi utilizado para averiguar se o fenômeno observado era resultante da variação entre os diferentes tratamentos e não de uma combinação aleatória. A segunda análise foi realizada para comparar tratamentos dois a dois e ver se estes eram significativamente diferentes entre si. Foram considerados significativos valores de $p<0,05$. 


\section{RESULTADOS}

\subsection{Modulação do processo de AICD em D011.10 por $\mathrm{PGE}_{2}$}

A $\mathrm{PGE}_{2}$ é um mediador lipídico liberado de forma basal em situações fisiológicas e em grandes quantidades durante as respostas imunológicas. Dados da literatura demonstram que esta molécula apresenta funções antagônicas, sendo capaz tanto de induzir quanto de inibir o processo de apoptose em determinadas condições.

No intuito de avaliar a capacidade da $\mathrm{PGE}_{2}$ em sensibilizar determinadas linhagens celulares ao processo de apoptose, inicialmente testamos se a $\mathrm{PGE}_{2}$ a ser utilizada está funcionando adequadamente em um sistema conhecido. Para tanto, utilizamos um modelo, previamente estabelecido por nosso grupo (85), no qual a $\mathrm{PGE}_{2}$ é capaz de proteger hibridomas de linfócitos T CD4+ (DO11.10) do processo de AICD. Neste modelo, hibridomas DO11.10 estimulados com CD3 agonistas imobilizados em placa, estímulo similar ao gerado via reconhecimento do complexo $\mathrm{MHC}$ + peptídeo de APCs pelo complexo TCR/CD3 de linfócitos T, são protegidos da apoptose de forma significativa na presença de $\mathrm{PGE}_{2}$ (Figura 2), mostrando que, de fato, a $\mathrm{PGE}_{2}$ utilizada nos experimentos apresentou atividade funcional. A análise da indução de apoptose foi realizada por citometria de fluxo através da marcação com PI presente no HFS, um tampão hipotônico que atua rompendo a membrana plasmática e permitindo que o PI se intercale no DNA de dupla fita e emita fluorescência. Na medida em que há fragmentação do DNA e, consequentemente, o aparecimento dos núcleos hipodiplóides, uma das características mais marcantes do processo de apoptose, a fluorescência vai diminuindo. 


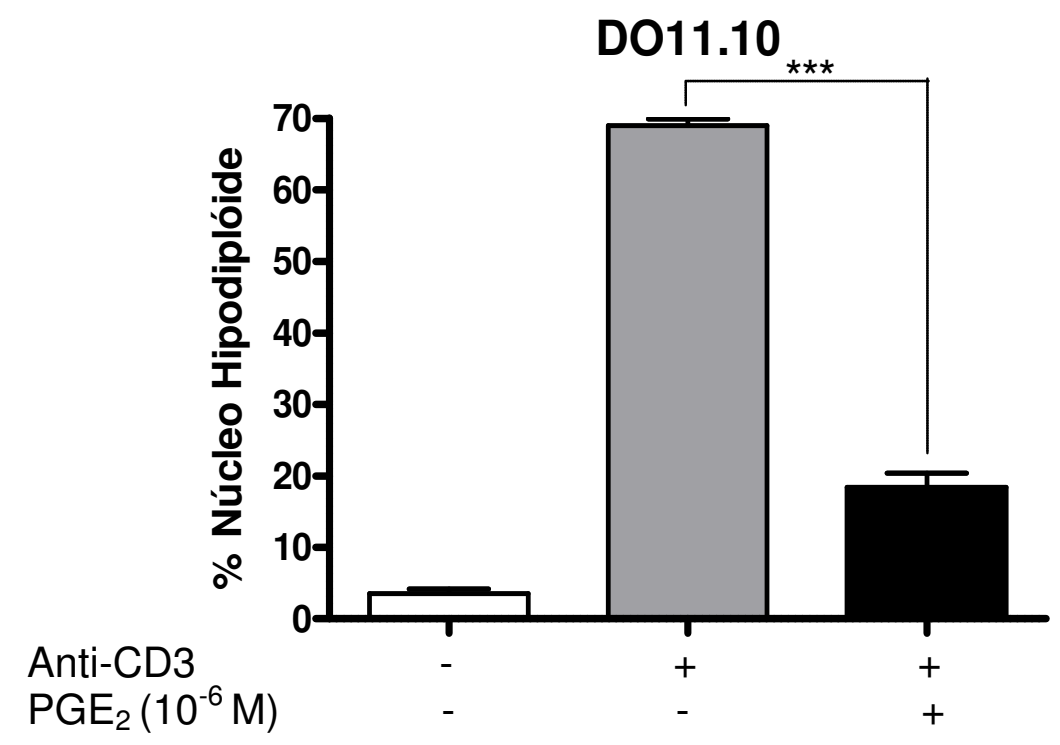

Figura 2. Modulação do processo de $A I C D$ em DO11.10 por $P G E_{2}$. Hibridomas de linfócitos $T$ DO11.10 $\left(2 \times 10^{5}\right.$ cels $\left./ 100 \mu \mathrm{L}\right)$ foram incubados por 18 horas com ou sem $1 \mu \mathrm{g} / \mathrm{mL}$ de CD3 (clone 2C11), imobilizados em placas de 96 poços, na presença ou não de $10^{-6} \mathrm{M}$ de $\mathrm{PGE}_{2}$. As taxas de apoptose foram analisadas por citometria de fluxo após incorporação de iodeto de propídeo em tampão HFS. As barras representam a média das triplicatas realizadas para cada tratamento e, acima destas, estão representados os respectivos desvios-padrão. $\left(^{* * *}\right)$ : Estatisticamente significativo entre as amostras demarcadas. $p<0,001$

De acordo com dados da literatura a indução de morte pela $\mathrm{PGE}_{2}$ é causada pelo seu reconhecimento via receptores EP2 e EP4, ou seja, pelo aumento de cAMP. A forsk (forskolina), um diterpeno capaz de ativar diretamente a adenilato ciclase independente de EPs, pode ser utilizada como controle positivo da ativação desse segundo mensageiro pela $\mathrm{PGE}_{2}$. Se por um lado a literatura mostra que 0 aumento de cAMP está relacionado à indução de morte em determinadas linhagens (100), por outro, dados previamente publicados pelo nosso grupo (85), indicam que este também é capaz de proteger os hibridomas de linfócitos T D011.10 do processo de AICD induzido pelo tratamento com CD3, semelhante a PGE 2 . Dessa forma, o mesmo modelo de indução de AICD utilizado para testar a prostaglandina, foi utilizado para avaliar a atividade funcional da forsk (Figura 3). 


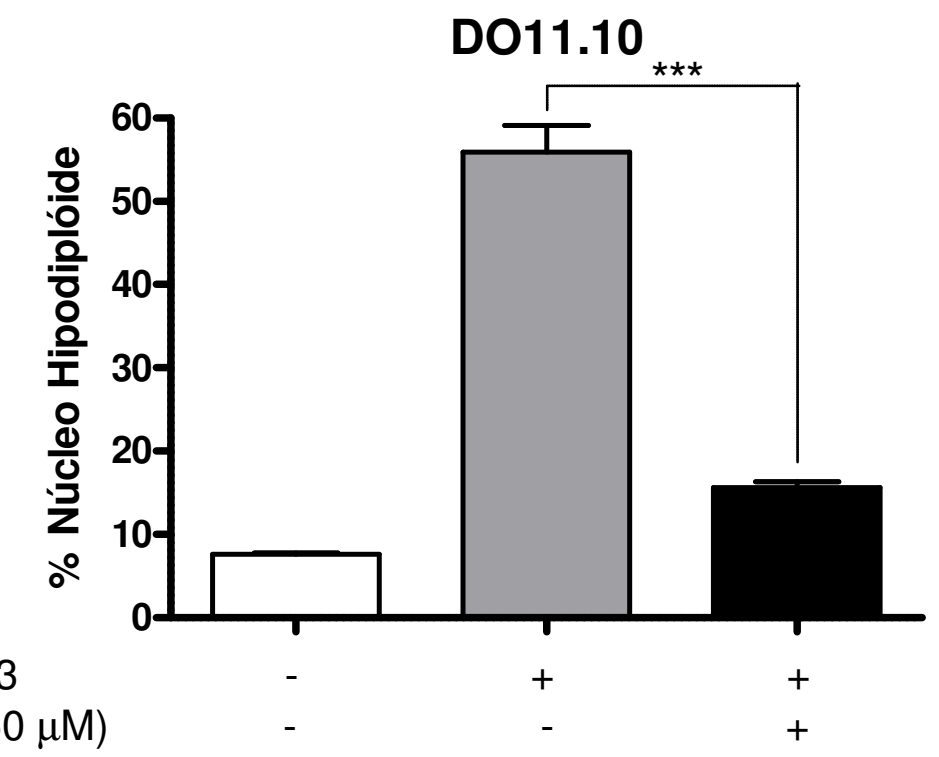

Figura 3. Modulação do processo de AICD em DO11.10 pela Forsk. Hibridomas de linfócitos T DO11.10 $\left(2 \times 10^{5}\right.$ cels $\left./ 100 \mu \mathrm{L}\right)$ foram incubados por $18 \mathrm{~h}$ com ou sem $1 \mu \mathrm{g} / \mathrm{mL}$ de CD3 (clone 2C11), imobilizados em placas de 96 poços, na presença ou não de $50 \mu \mathrm{M}$ de Forsk. As taxas de apoptose foram analisadas por citometria de fluxo após incorporação de iodeto de propídeo em tampão HFS. As barras representam a média das triplicatas realizadas para cada tratamento e, acima destas, estão representados os respectivos desvios-padrão. $\left(^{* \star \star}\right)$ : Estatisticamente significativo entre as amostras demarcadas. $p<0,001$

\subsection{Sensibilização à apoptose em D011.10 por $\mathrm{PGE}_{2}$}

Uma vez que já foi demonstrado pelo nosso grupo (85) que as células D011.10 apresentam os receptores específicos e respondem a $\mathrm{PGE}_{2}$, o próximo passo foi investigar a sensibilização à apoptose por esta molécula, nestas células. Para induzir o processo de morte neste modelo, foi utilizado o CD95L (FASL) solúvel, que se liga ao receptor CD95 (FAS) e induz apoptose pela via extrínseca, simulando a interação entre FAS/FASL que ocorre fisiologicamente no organismo.

Primeiramente, foi realizado o tratamento dos linfócitos T DO11.10 com três diferentes concentrações $(0,02 ; 0,2$ e $2 \mathrm{ng} / \mu \mathrm{L})$ de CD95L, e embora todas tenham sido capazes de induzir apoptose de forma significativa, a concentração intermediária de $0,2 \mathrm{ng} / \mathrm{\mu L}$ foi a ideal, uma vez que tanto uma resistência quanto uma sensibilização a apoptose poderiam ser facilmente identificadas (Figura 4). 
D011.10

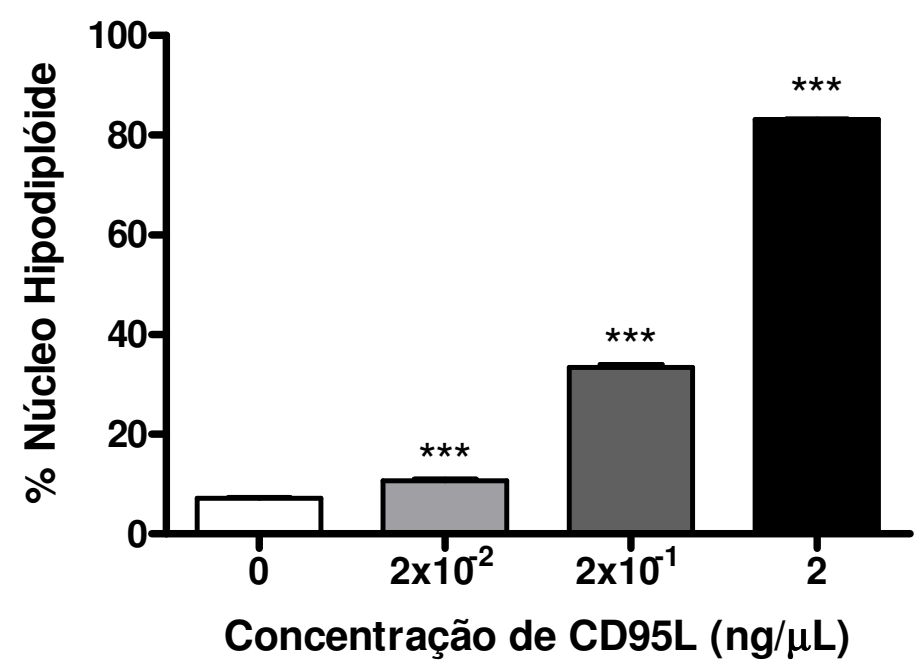

Figura 4. Indução de apoptose em D011.10 por CD95L. Hibridomas de linfócitos T D011.10 $\left(2 \times 10^{5}\right.$ cels $\left./ 100 \mu \mathrm{L}\right)$ foram estimulados ou não com diferentes concentrações de CD95L $(0,02 ; 0,2$ e $2 \mathrm{ng} / \mu \mathrm{L})$ por 18 horas em placas de 96 poços. A análise foi feita por citometria de fluxo após incorporação de iodeto de propídeo em tampão HFS. As barras representam a média das triplicatas realizadas para cada tratamento e, acima destas, estão representados os respectivos desvios-padrão. $\left.{ }^{* * *}\right)$ : Estatisticamente significativo em relação ao controle. $p<0,001$

Uma vez padronizada a concentração de $0,2 \mathrm{ng} / \mathrm{\mu L}$, indutora de 30 a $40 \%$ de apoptose nas células D011.10, o próximo passo foi avaliar o efeito do tratamento das células DO11.10 com CD95L em associação com $\mathrm{PGE}_{2}$. Como mostra a figura $5 \mathrm{~A}$, a $P \mathrm{PE}_{2}$ não foi capaz de sensibilizar as células. $A$ taxa de apoptose foi avaliada por citometria de fluxo através da marcação com anexina $\mathrm{V}$, a qual apresenta alta afinidade por resíduos de fosfatidilserina, externalizados durante o processo apoptótico. Além da prostaglandina, a forsk também foi testada em associação com o CD95L (Figura 5B), revelando um aumento significativo da apoptose. Entretanto, a forsk, por si só, tem um efeito tóxico para as células, sendo que esta poderia ser a causa do aumento na taxa de morte. 
A
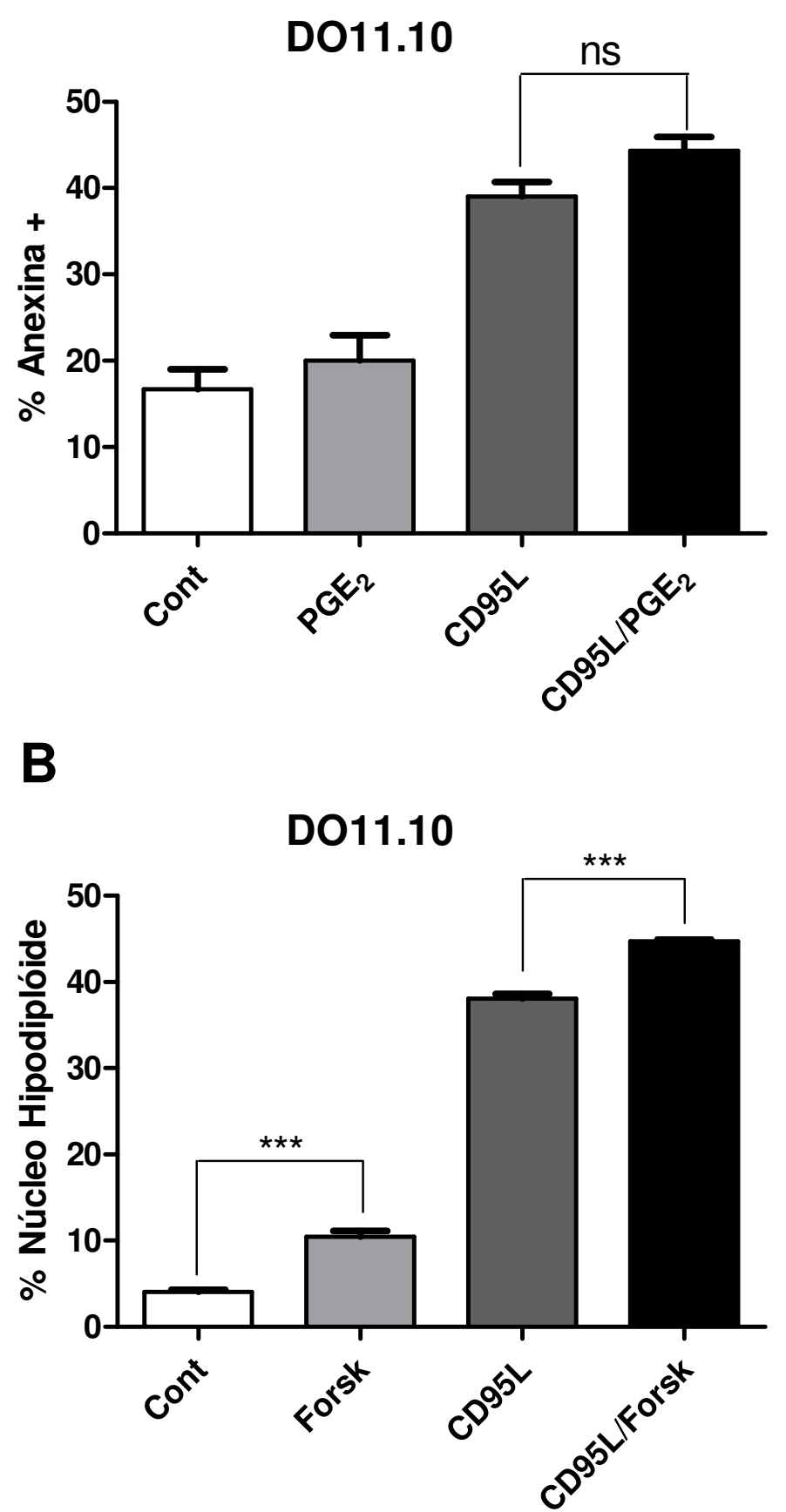

Figura 5. Análise da sensibilização de apoptose via FAS por $P G E_{2}$ e forsk em DO11.10. Hibridomas de linfócitos T DO11.10 $\left(2 \times 10^{5}\right.$ cels $\left./ 100 \mu \mathrm{L}\right)$ foram estimulados ou não com $0,2 \mathrm{ng} / \mathrm{\mu L}$ de CD95L em placas de 96 poços por 18 horas na presença ou não de $10^{-6} \mathrm{M}$ de $P G E_{2}$ (A) ou de $50 \mu \mathrm{M}$ de Forsk (B). As barras representam a média das triplicatas realizadas para cada tratamento e, acima destas, estão representados os respectivos desvios-padrão. (ns): Não significativo entre as amostras demarcadas. $\left(^{* * *}\right)$ : Estatisticamente significativo entre as amostras demarcadas. $p<0,001$ 
Em contrapartida, também é importante levar em consideração que a forsk, por se ligar diretamente a adenilato cliclase, poderia sensibilizar essas células em um menor espaço de tempo, o que explicaria o aumento encontrado na taxa de morte. Assim, supomos que a $\mathrm{PGE}_{2}$ necessite de um tempo relativamente maior para sensibilizar as células antes que estas entrem em contato com o CD95L. Para investigar tal possibilidade, realizamos uma cinética na qual a $\mathrm{PGE}_{2}$ foi adicionada à cultura de linfócitos T DO11.10 em diferentes períodos (0, -2, -4 e -6 h) previamente a adição do CD95L. A figura 6 mostra, entretanto, que mesmo após o tempo máximo de 6 horas de tratamento com $\mathrm{PGE}_{2}$, nenhuma diferença significativa pôde ser observada.

\section{D011.10}

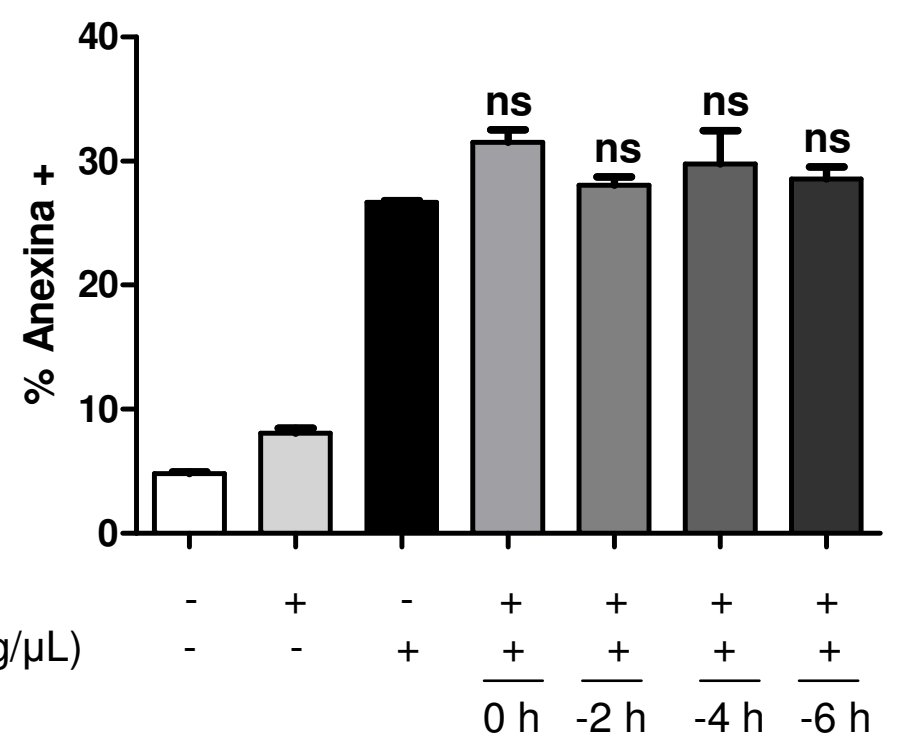

Figura 6. Cinética do tratamento de $P G E_{2}$ e CD95L em DO11.10. Duzentas mil células foram tratadas com $10^{-6} \mathrm{M}$ de $P G E_{2}$ no tempo $0,2,4$ e $6 \mathrm{~h}$ antes da estimulação ou não com $0,2 \mathrm{ng} / \mu \mathrm{L}$ de CD95L em placas de 96 poços por 18 horas. A análise foi realizada por citometria de fluxo através da ligação de anexina $V$ aos resíduos de fosfatidilserina liberados durante o processo de apoptose. As barras representam a média das triplicatas realizadas para cada tratamento e, acima destas, estão representados os respectivos desvios-padrão. (ns): Não foi estatisticamente significativo em comparação ao tratamento com CD95L.

Em todos os dados mostrados anteriormente, utilizamos a concentração de $50 \mu \mathrm{M}$ de forsk, escolhida de acordo com experimentos previamente realizados pelo nosso grupo, e $10^{-6} \mathrm{M}$ de $\mathrm{PGE}_{2}$, concentração encontrada em sobrenadantes de células apresentadoras de antígenos estimuladas por LPS (101), ou seja, a concentração que, provavelmente, mais se aproxima da fisiológica. Sendo assim, é 
possível que estes efeitos de sensibilização à apoptose, em particular, sejam causados por concentrações menores de $\mathrm{PGE}_{2}$ e que a escolhida talvez não tenha sido a mais adequada. Para avaliar qual seria a concentração ideal de $\mathrm{PGE}_{2}$ e de forsk neste modelo, realizamos novos testes tratando as células com a mesma concentração de CD95L em combinação com diferentes concentrações tanto de $\mathrm{PGE}_{2}$ quanto de forsk (Figura $7 \mathrm{~A}$ ). Em paralelo, realizamos o tratamento dessas mesmas células com CD3 no lugar de CD95L, a fim de comparar o efeito da $\mathrm{PGE}_{2} \mathrm{e}$ da forsk no modelo de AICD, o qual já está bem estabelecido, com o modelo de sensibilização testado no momento (Figura 7B).

Enquanto todas as concentrações de $\mathrm{PGE}_{2}$ e de forsk testadas, exceto a de $10^{-10} \mathrm{M}$ de $\mathrm{PGE}_{2}$, foram capazes de inibir significativamente o processo de AICD, nenhuma delas das concentrações foi capaz de sensibilizar estas mesmas células à morte induzida por CD95L. Este experimento nos fornece um controle positivo demonstrando que o problema não está na capacidade funcional dessas moléculas. 
A

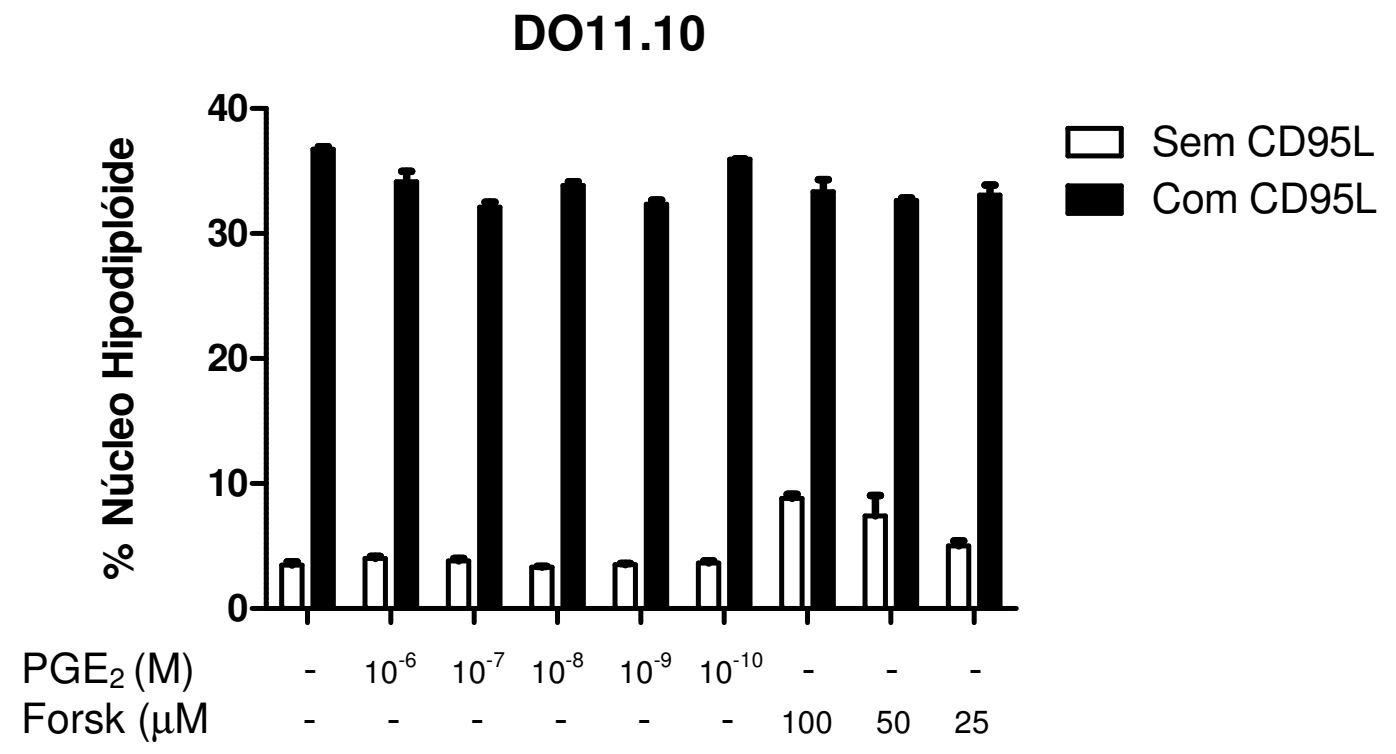

B

D011.10

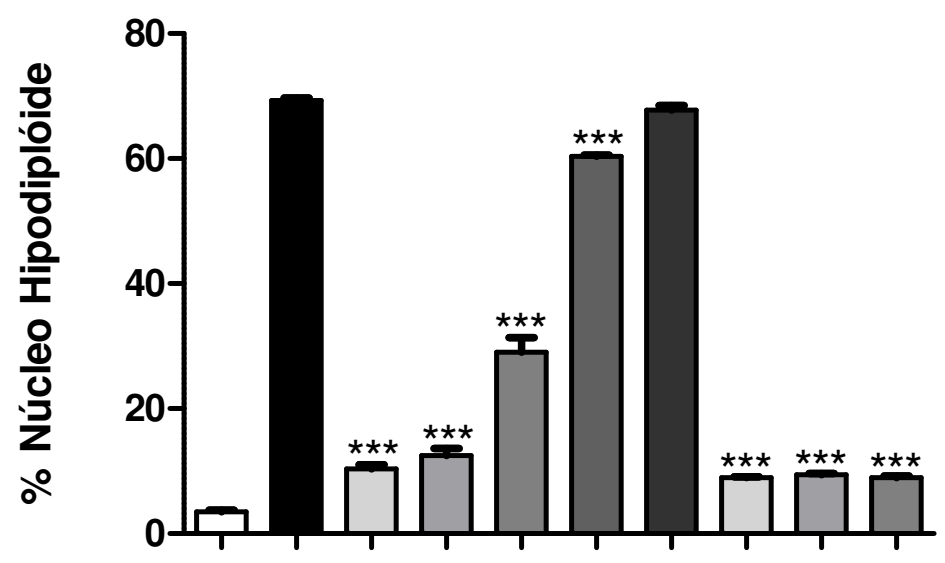

Anti-CD3

$\mathrm{PGE}_{2}(\mathrm{M})$

Forsk $(\mu \mathrm{M})$

Figura 7. Análise da sensibilização de apoptose via FAS por diferentes concentrações de $P G E_{2} e$ Forsk. Hibridomas de linfócitos T DO11.10 $\left(2 \times 10^{5}\right.$ cels/100 $\left.\mu \mathrm{L}\right)$ foram estimulados ou não com $0,2 \mathrm{ng} / \mu \mathrm{L}$ de CD95L em placas de 96 poços, por 18 horas na presença ou não de diferentes concentrações de $\mathrm{PGE}_{2}$ ou de Forsk (A). Em paralelo, as mesmas concentrações de $\mathrm{PGE}_{2}$ e Forsk foram utilizadas para inibir o processo de AICD (B). A análise foi feita por citometria de fluxo após incorporação de iodeto de propídeo em tampão HFS. As barras representam a média das triplicatas realizadas para cada tratamento e, acima destas, estão representados os respectivos desvios-padrão. $\left.{ }^{* \star \star}\right)$ : Estatisticamente significativo em relação ao tratamento com CD3. $p<0,001$ 
Está claro na literatura que, em um estado fisiológico, diversas vias de sinalização são ativadas simultaneamente em uma mesma célula. No caso de um linfócito, por exemplo, durante uma infecção, ao mesmo tempo em que há presença de peptídeos sendo apresentados a estas células via MHC das APCs, diversas moléculas produzidas por estas $\mathrm{APCs}$, como a $\mathrm{PGE}_{2}$, são liberadas atuando através de seus receptores específicos. Tudo isso pode acontecer simultaneamente e não necessariamente de forma isolada. Partindo desse pressuposto, o próximo passo foi investigar se dentro do contexto de AICD, onde ocorre uma ativação do complexo TCR, a adição de $\mathrm{PGE}_{2}$ concomitantemente com o CD95L, resultaria na sensibilização dessas células a apoptose, o que poderia ser resultado de uma comunicação entre a via bioquímica induzida pela $P \mathrm{PE}_{2}$ e a induzida pelo TCR, gerando um efeito de sensibilização ao FAS nessas células.

Sabe-se que a $\mathrm{PGE}_{2}$ é capaz de proteger os hibridomas de linfócitos $T$ D011.10 do processo de AICD induzido com CD3, através da diminuição da expressão de FASL, que aumenta durante a indução de AICD. Porém, se neste contexto a $\mathrm{PGE}_{2}$ leva a uma diminuição dos níveis de $\mathrm{FASL}$, por outro lado, poderia sensibilizar as células pela via do receptor FAS, o que resultaria em um aumento da morte quando o FASL exógeno fosse adicionado.

Para testar essa hipótese, os linfócitos T DO11.10 foram estimulados ou não (controle) com CD3 imobilizados em placa na presença ou não de $\mathrm{PGE}_{2}$ e/ou CD95L. A figura 8 nos mostra que a adição de CD95L à cultura de D011.10 tratadas com $\mathrm{CD} 3$ e $\mathrm{PGE}_{2}$ tornam estas células novamente sensíveis ao processo de apoptose, o que sugere um efeito aditivo da morte por CD3 e por CD95L. Assim, células estimuladas com $\mathrm{CD} 3$ na presença de $\mathrm{PGE}_{2}$ incorporaram cerca de $30 \%$ de anexina, enquanto aquelas estimuladas apenas com CD95L incorporaram praticamente a mesma quantidade. Quando CD95L é adicionado ao ensaio com CD3 e $\mathrm{PGE}_{2}$, a porcentagem de morte se aproxima da marca de $60 \%$. Essa sensibilidade é ainda menor quando comparada a das células estimuladas apenas por CD3, o que sugere ausência desse efeito (Figura 8).

Tomados em conjunto, esses dados sugerem que a $\mathrm{PGE}_{2}$ não é capaz de sensibilizar hibridomas de linfócitos T DO11.10 à apoptose induzida por CD95L solúvel. 


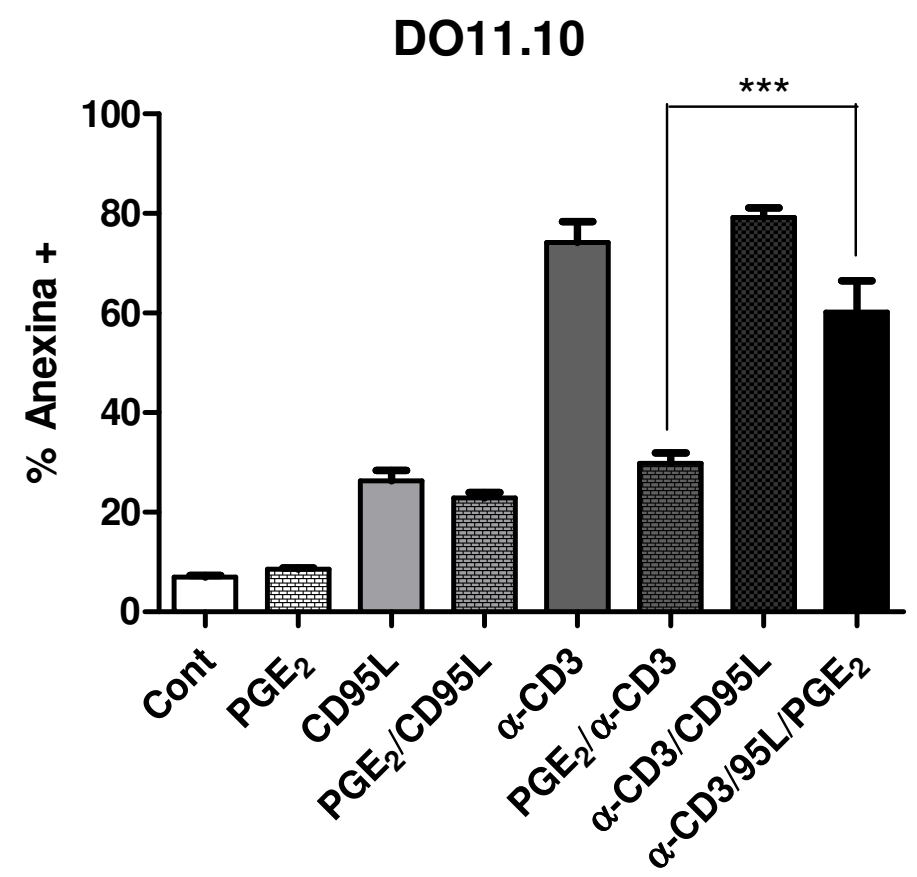

Figura 8. Efeito da comunicação entre as vias bioquímicas induzidas pela $P G E_{2}$ e pelo complexo do TCR. Hibridomas de linfócitos T DO11.10 $\left(2 \times 10^{5}\right.$ cels/100 $\left.\mu \mathrm{L}\right)$ foram estimulados ou não (controle) com $1 \mu \mathrm{g} / \mathrm{mL}$ de CD3 (clone 2C11) imobilizados em placas de 96 poços por 18 horas na presença ou não de $0,2 \mathrm{ng} / \mu \mathrm{L}$ de CD95L e/ou de $10^{-6} \mathrm{M}$ de $\mathrm{PGE}_{2}$. A análise foi realizada por citometria de fluxo através da ligação de anexina $V$ aos resíduos de fosfatidilserina liberados durante o processo de apoptose. As barras representam a média das triplicatas realizadas para cada tratamento e, acima destas, estão representados os respectivos desvios-padrão. $\left.{ }^{(* *}\right)$ : Estatisticamente significativo entre as amostras demarcadas. $p<0,001$

\subsection{Caracterização de células Tipo I e Tipo II}

Mesmo tendo obtido resultados negativos com hibridomas de linfócitos $T$ DO11.10, investigamos a sensibilização ao processo de apoptose pela $\mathrm{PGE}_{2}$ em outras células. As linhagens tumorais utilizadas foram células Tipo I (SKW.6.4 e SKW.6.4.BCL-2) e Tipo II (CEM e CEM.BCL-2 e HL-60, HL-60.BCL-2 e HL-60.BCL$\mathrm{X}_{\mathrm{L}}$ ). A transfecção estável das linhagens selvagens foi previamente realizada mediante infecção com retrovírus contendo apenas os vetores vazios ou os genes específicos de BCL-2 ou BCL- $X_{L}$, capazes de se integrar ao DNA da célula (57). A superexpressão dessas proteínas foi confirmada através da técnica de western blot, como mostra a figura 9 . 
A

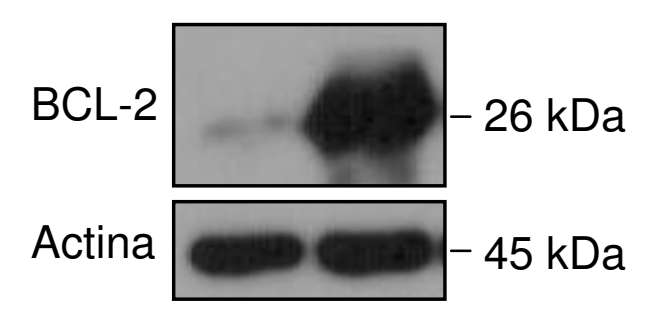

BCL-2

B

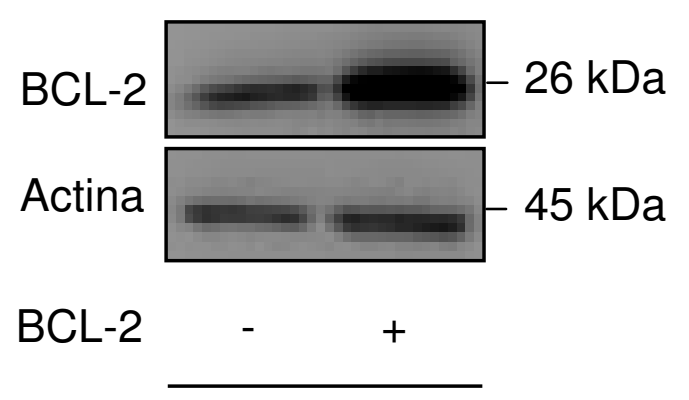

CEM

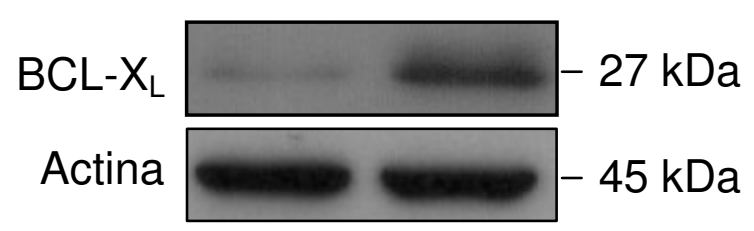

BCL-X $\quad-\quad+$

HL-60

HL-60

Figura 9. Expressão protéica das moléculas antiapoptóticas $B C L-2$ e $B C L-X_{L}$ em células Tipo I e Tipo II. Lisados protéicos foram preparados a partir da cultura de células SKW.6.4 (A) e CEM (B), transfectadas ou não com BCL-2, e HL-60 (C), transfectadas ou não com BCL2 ou BCL-X $\mathrm{X}_{\mathrm{L}}$, em meio RPMI 10\% FCS. A expressão dessas moléculas foi analisada através da técnica de Western blot em gel de poliacrilamida a $12 \%$.

Uma vez confirmada a superexpressão de BCL-2 e BCL- $X_{L}$ nestas linhagens, avaliamos a capacidade funcional dessas proteínas na inibição do processo de apoptose. Para tanto, as linhagens em questão foram tratadas com drogas que estimulam a apoptose pela via intrínseca, ou seja, com participação da mitocôndria, onde as proteínas de interesse exercem sua atividade antiapoptótica, independente da célula se comportar como Tipo I ou como Tipo II. Dentre as drogas utilizadas, a $\mathrm{CHX}$ atua inibindo o processo de tradução de proteínas vitais para células eucariotas, o que resulta na morte da mesma. Já a AraC atua inibindo a síntese de DNA por se incorporar em determinados sítios da fita. Como mostra a figura 10, o processo de apoptose foi induzido em células selvagens, mas inibido de forma 
significativa pela superexpressão de BCL-2 ou BCL-X tanto em células Tipo I (Figura 10A) quanto em células Tipo II (Figura 10B e C).

É importante ressaltar que algumas linhagens, tais como CEM e HL-60 podem expressar uma quantidade basal de determinadas proteínas antiapoptóticas, como BCL-2 (Figura 9B e C), que não são suficientes para proteger essas células do processo de morte quando ocorre indução de apoptose (Figura 10B e C), sendo necessária a superexpressão dessas proteínas.

A

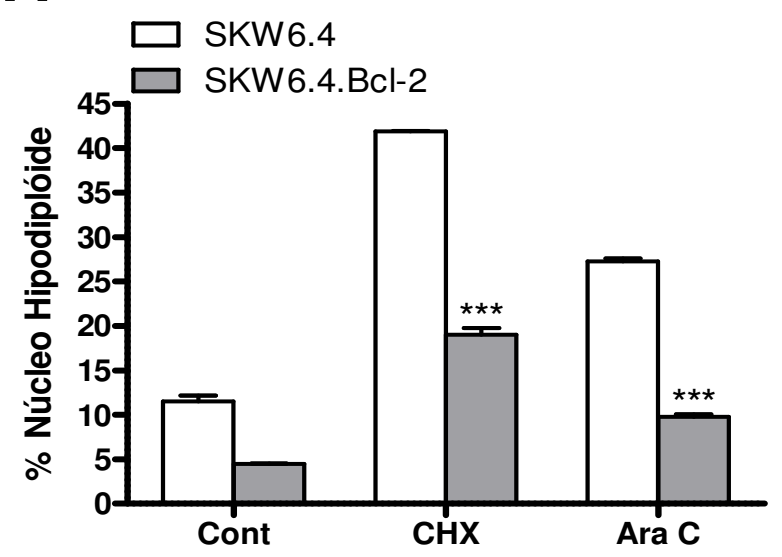

B

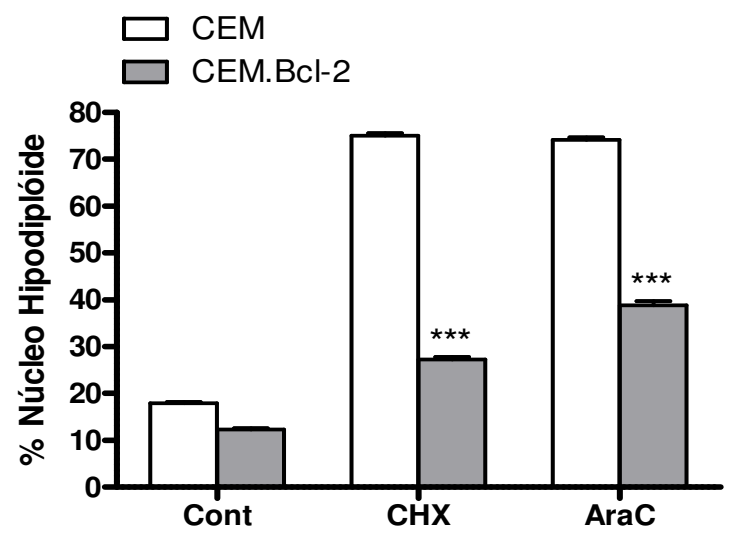

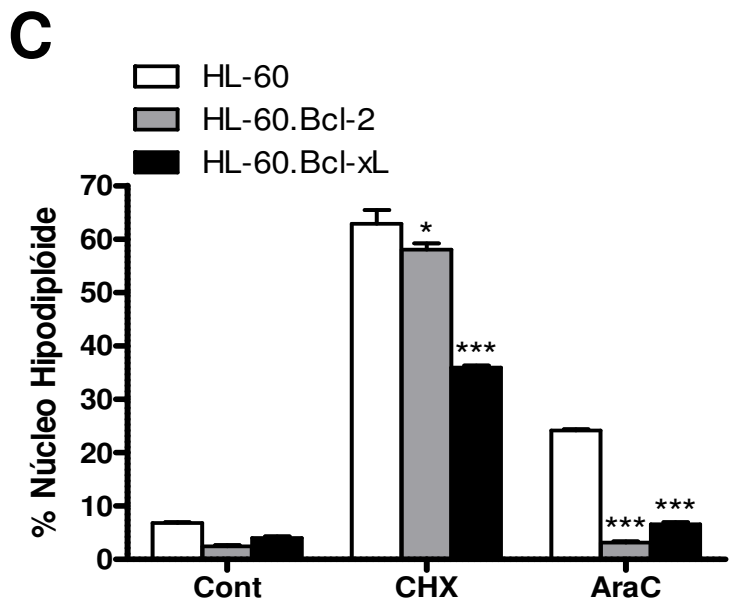

Figura 10. Indução de apoptose via intrínseca em células Tipo I e Tipo II. As linhagens celulares SKW.6.4 e SKW.6.4.BCL-2 (A), CEM e CEM.BCL-2 (B) e HL-60, HL-60.BCL-2 e HL60.BCL-X $\mathrm{X}_{\mathrm{L}}$ (C) foram incubadas por 18 horas sem (controle) ou com $50 \mu \mathrm{M}$ de $\mathrm{CHX}$ e 1 $\mu \mathrm{M}$ de AraC. A análise foi realizada por citometria de fluxo após incorporação de iodeto de propídeo em tampão HFS. As barras representam a média das triplicatas realizadas para cada tratamento e, acima destas, estão representados os respectivos desviospadrão. Estatisticamente significativo em comparação a barra branca de cada tratamento. ${ }^{*} p<0,05 \quad{ }^{* * *} p<0,001$ 
Por outro lado, quando a apoptose é estimulada pela via extrínseca, as linhagens se comportam de forma diferente, deixando clara a existência de dois tipos distintos de células. A apoptose foi induzida neste modelo pelo tratamento com anticorpos agonistas anti-FAS humano (clone $\mathrm{CH} 11$ ), os quais reconhecem e se ligam ao receptor FAS, comportando-se da mesma forma que o FASL. Enquanto células Tipo I tornam-se novamente sensíveis a apoptose, apesar da superexpressão de BCL-2 (Figura 11A), células Tipo II continuam resistentes a apoptose nas mesmas condições (Figura 11B e C).

A

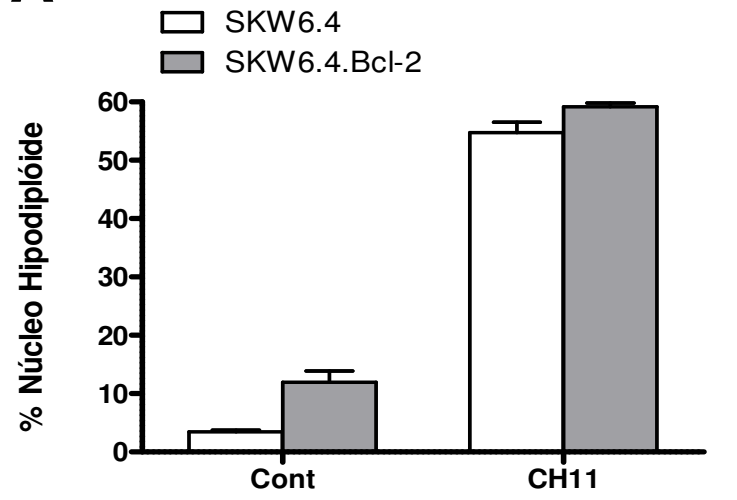

C

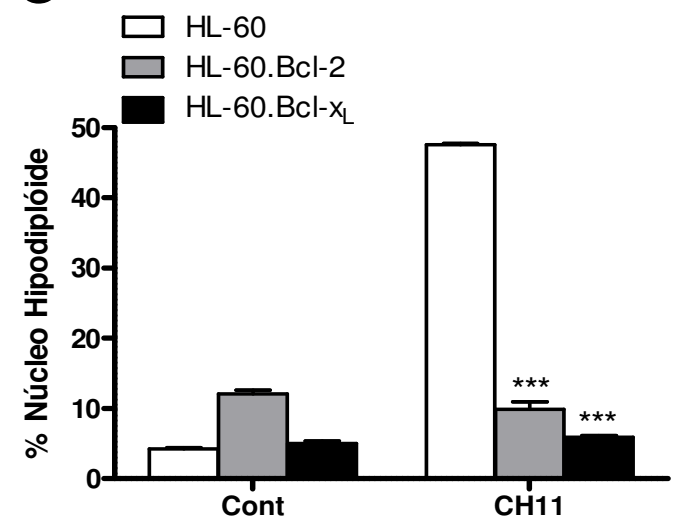

B

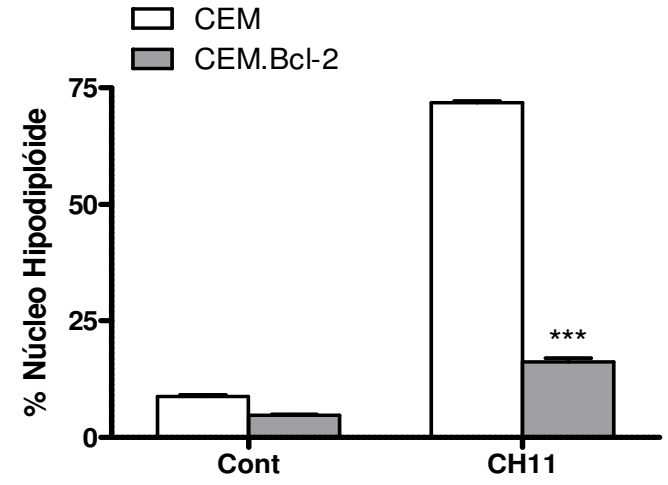

Figura 11. Indução de apoptose via extrínseca em células Tipo I e Tipo II. As linhagens celulares SKW.6.4 e SKW.6.4.BCL-2 (A), CEM e CEM.BCL-2 (B) e HL-60, HL-60.BCL-2 e HL60.BCL- $X_{\mathrm{L}}$ (C) foram incubadas por 18 horas sem (controle) ou com $0,25 \mu \mathrm{g} / \mathrm{mL}$ (A e B) ou $1 \mu \mathrm{g} / \mathrm{mL}$ (C) de $\mathrm{CH} 11$. A análise foi realizada por citometria de fluxo após incorporação de iodeto de propídeo em tampão HFS. As barras representam a média das triplicatas realizadas para cada tratamento e, acima destas, estão representados os respectivos desvios-padrão. Estatisticamente significativo em comparação a barra branca do tratamento com $\mathrm{CH} 11 .{ }^{* * *} p<0,001$ 


\subsection{Sensibilização a apoptose por $\mathrm{PGE}_{2}$ em células Tipo I e Tipo II}

A $\mathrm{PGE}_{2}$, ao contrário da $\mathrm{CHX}$, atua nas células através do seu reconhecimento por receptores específicos EP1-EP4 (107). Sendo assim, o primeiro passo foi investigar nas linhagens celulares de interesse a capacidade destas de expressar tais receptores em suas membranas. Para tanto, foram preparados lisados protéicos de culturas celulares das linhagens Tipo I e Tipo II para a análise da expressão dos receptores EP1 a EP4, pela técnica de western blot. Como controle utilizamos hibridomas de linfócitos T DO11.10 que, como já havia sido descrito pelo nosso grupo (85) expressaram EP2, EP3 e EP4, mas não expressaram EP1. Células Tipo I e Tipo I| expressaram, sobretudo, EP3 e apresentaram baixa expressão de EP1, EP2 e EP4 (Figura 12). É importante observar que as proteínas antiapoptóticas, BCL-2 e BCL-X $\mathrm{X}_{\mathrm{L}}$, parecem causar um leve aumento na expressão desses três últimos receptores. De acordo com as modificações pós-translacionais dos receptores EP3 e EP4, podemos observar proteínas de diferentes tamanhos.

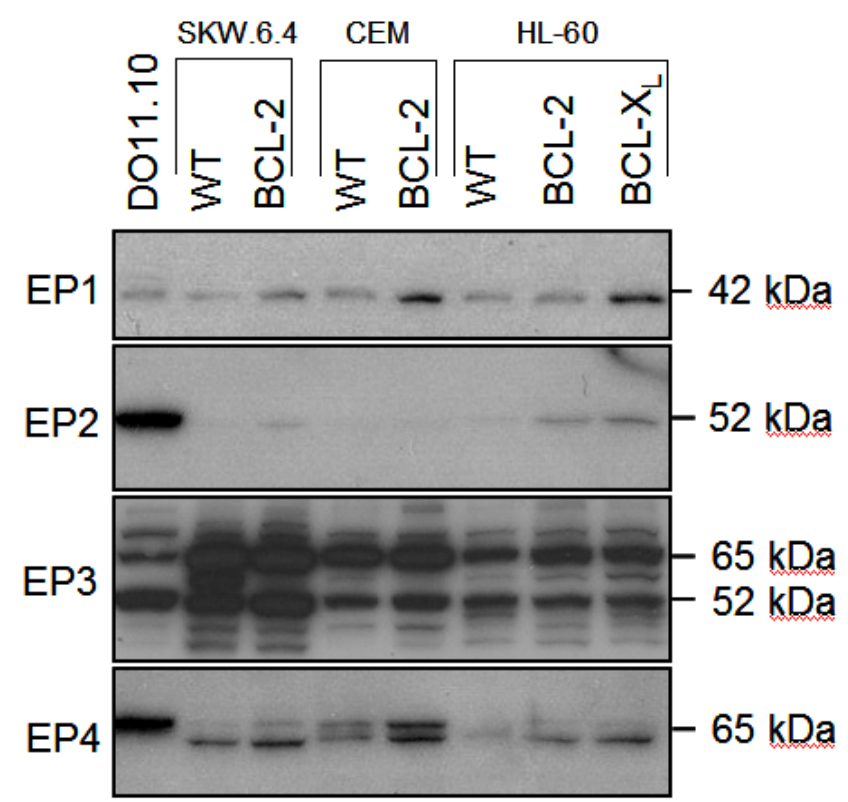

Figura 12. Expressão protéica dos receptores EP1-EP4, específicos para $P G E_{2}$. Lisados protéicos foram preparados a partir da cultura de células DO11.10 (D), SKW.6.4 (S), SKW.6.4.BCL-2 (108), CEM (C), CEM.BCL-2 (CB), HL-60 (H), HL-60.BCL-2 (HB) e HL60.BCL- $\mathrm{X}_{\mathrm{L}}(\mathrm{HL})$ em meio RPMI 10\% FCS. A expressão dessas moléculas foi analisada através da técnica de Western blot. 
Uma vez detectada a expressão dos receptores de interesse, avaliamos a capacidade da $\mathrm{PGE}_{2}$ em sensibilizar essas células à apoptose induzida pela via extrínseca. Para tanto, células Tipo I e Tipo II foram tratadas com anticorpos agonistas anti-FAS humano na presença ou não de $\mathrm{PGE}_{2}$. Contudo, a sensibilização esperada não foi observada e também não houve nenhum efeito de proteção (Figura 13).

$A$
$\frac{0}{0}$
$\frac{0}{0}$
$\frac{0}{0}$
$\frac{0}{1}$
$\frac{8}{0}$
$\frac{0}{2}$
$\circ$
$\circ$

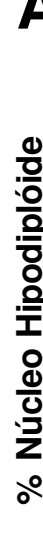

$\mathrm{CH} 11$ $\mathrm{PGE}_{2}$

일
SKW.6.4

SKW.6.4.BCL-2<smiles>C1CC1</smiles>

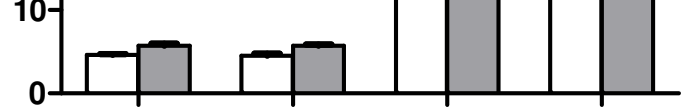

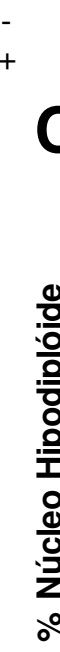

C
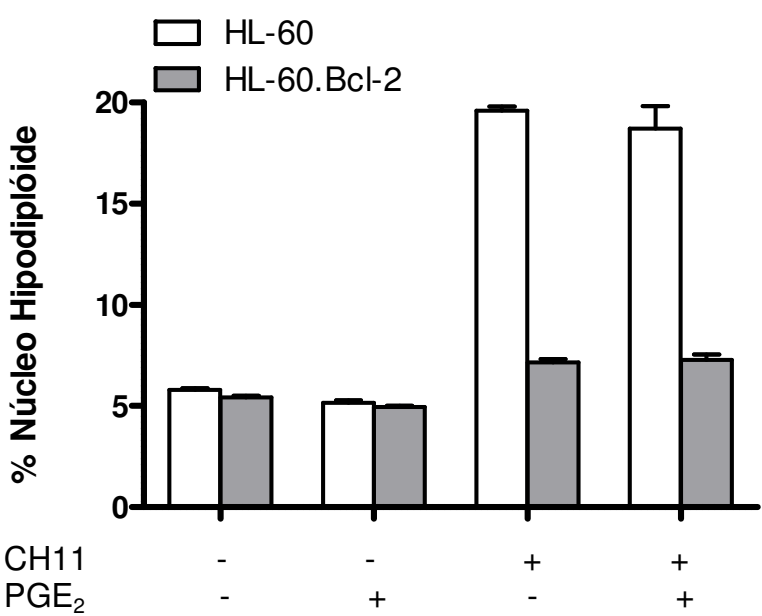

Figura 13. Efeito do tratamento com $P G E_{2}$ em células Tipo I e Tipo II. As linhagens celulares SKW.6.4 e SKW.6.4.BCL-2 (A), CEM e CEM.BCL-2 (B) e HL-60 e HL-60.BCL-2 (C) foram incubadas por 18 horas sem (controle) ou com $1 \mu \mathrm{g} / \mathrm{mL}$ de $\mathrm{CH} 11$ na presença ou não de $10^{-6} \mathrm{M}$ de $\mathrm{PGE}_{2}$. A análise foi realizada por citometria de fluxo após incorporação de iodeto de propídeo em tampão HFS. As barras representam a média das triplicatas realizadas para cada tratamento e, acima destas, estão representados os respectivos desvios-padrão. Não houve resultado estatisticamente significativo.

Embora tenhamos demonstrado que as linhagens celulares Tipo I e Tipo II expressaram os receptores específicos para $\mathrm{PGE}_{2}$, é preciso lembrar que EP2 e 
EP4, os receptores de nosso interesse, estavam presentes em baixas quantidades. Sendo assim, para excluir a hipótese de que a prostaglandina não estivesse sendo adequadamente reconhecida, as linhagens foram novamente tratadas com $\mathrm{CH} 11$, porém agora na presença ou não de forsk em vez de $\mathrm{PGE}_{2}$, proporcionando uma ativação direta das vias bioquímicas induzidas pelo reconhecimento através dos receptores EP2 e EP4, os responsáveis pelo aumento do cAMP.

Entretanto, assim como a $\mathrm{PGE}_{2}$, a forsk também não foi capaz de sensibilizar as células ao processo de apoptose, nem de realizar a conversão de células Tipo II em Tipo I, uma vez que mesmo após o tratamento, a proteína BCL-2 continuou exercendo suas atividades antiapoptóticas (Figura 14).

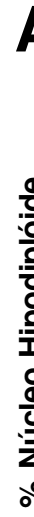

A

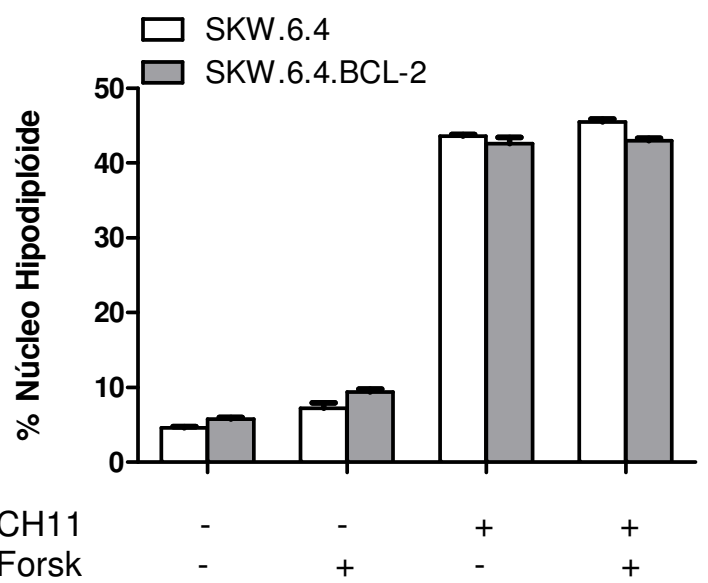

C $\square \mathrm{HL}-60$

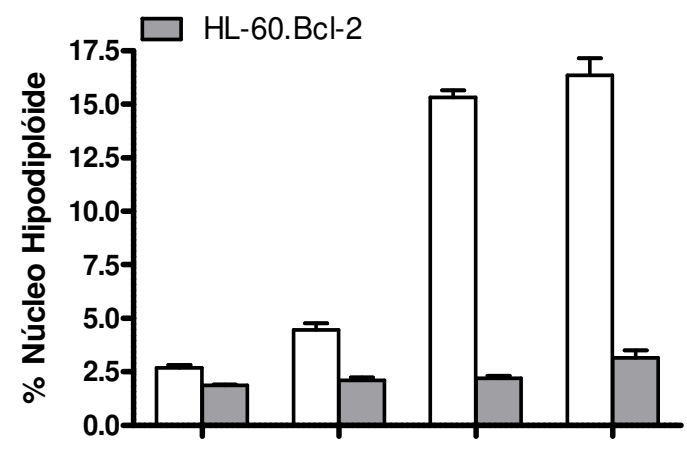

$\mathrm{CH} 11$

Forsk

Forsk
B

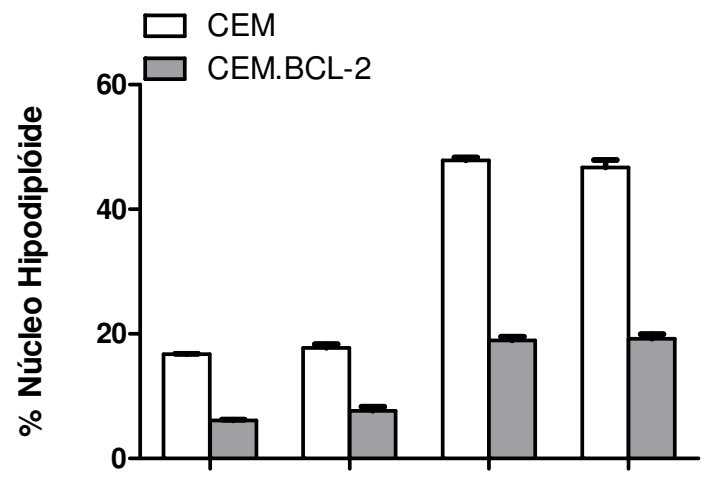

$\mathrm{CH} 11$

Forsk

Figura 14. Efeito do tratamento com Forsk em células Tipo I e Tipo II. As linhagens celulares SKW.6.4 e SKW.6.4.BCL-2 (A), CEM e CEM.BCL-2 (B) e HL-60 e HL-60.BCL-2 (C) foram incubadas por 18 horas sem (controle) ou com $1 \mu \mathrm{g} / \mathrm{mL}$ de $\mathrm{CH} 11$ na presença ou não de $50 \mu \mathrm{M}$ de Forsk. A análise foi realizada por citometria de fluxo após incorporação de iodeto de propídeo em tampão HFS. As barras representam a média das triplicatas realizadas para cada tratamento e, acima destas, estão representados os respectivos desvios-padrão. Não houve resultado estatisticamente significativo. 


\section{DISCUSSÃO}

O estudo da modulação da morte mediada por FAS é de suma importância, uma vez que o processo de apoptose participa de muitas condições fisiopatológicas, garantindo a homeostasia do sistema imune e a desregulação desse processo está associada a uma série de desordens, tais como câncer, doenças autoimunes e imunodeficiências. Nesse estudo, em particular, nos concentramos em investigar o papel da $\mathrm{PGE}_{2}$ nessa modulação. A nossa hipótese era de que a prostaglandina fosse capaz de sensibilizar hibridomas de linfócitos $T$ D011.10 e linhagens celulares denominadas Tipo I e Tipo II ao processo de apoptose, além de converter células Tipo II em Tipo I.

Inicialmente, testamos a $\mathrm{PGE}_{2}$ e a forsk - utilizada como controle positivo do aumento de CAMP - no modelo já bem estabelecido de AICD. Ambas as moléculas revelaram-se funcionais visto que inibiram o processo de apoptose em hibridomas de linfócitos T DO11.10. Isso valida os dados previamente publicados pelo nosso grupo (85) e está de acordo com diversos dados da literatura (86, 99). Todavia, apesar de haver dados na literatura demonstrando o efeito antiapoptótico da $\mathrm{PGE}_{2}$, outros trabalhos têm mostrado que esta molécula também pode atuar como próapoptótica em determinadas situações $(100,109)$. Entretanto quando a $\mathrm{PGE}_{2}$ e a forsk foram testadas no nosso modelo de indução de morte, nenhuma sensibilização a apoptose foi observada. Essas diferenças encontradas na atividade da $P \mathrm{PE}_{2}$ dependem, principalmente, das diferentes proteínas $G$ acopladas aos seus receptores específicos e do estágio de maturação, localização tecidual e linhagem das células em que esses receptores estão presentes $(88,107,110)$.

Diversas variáveis foram avaliadas na tentativa de encontrar um modelo no qual a $\mathrm{PGE}_{2}$ fosse capaz de sensibilizar as células. Nesse aspecto, é importante ressaltar, em primeiro lugar, que resultados preliminares obtidos pelo nosso grupo (101) demonstraram que a concentração do mediador lipídico para exercer o efeito de sensibilização foi significantemente menor do que o necessário para proteger os hibridomas DO11.10 da AICD. Por isso diferentes concentrações foram testadas e nenhuma delas foi capaz de alterar o perfil de morte dessas células.

Outro ponto a ser considerado é o de que a $\mathrm{PGE}_{2}$ poderia necessitar de um contato prévio com as células antes da interação destas com em o CD95L (109). É 
plausível pensar que se o receptor FAS é constitutivo na maioria dos tecidos do corpo, imediatamente após a adição do CD95L, este imediatamente se ligaria ao receptor FAS iniciando o processo de apoptose $(108,111)$. Isso impossibilitaria a sensibilização pela $\mathrm{PGE}_{2}$ que ainda precisaria ser reconhecida por um ou mais de seus receptores específicos para então iniciar a sinalização intracelular. Entretanto, a cinética do tratamento com $\mathrm{PGE}_{2}$ e posterior indução de apoptose por CD95L não apresentou resultados interessantes, mantendo o mesmo padrão dos experimentos anteriores. Mais um aspecto importante a ser lembrado, é que em um contexto imunológico, os eventos não ocorrem de forma isolada e diversas vias de sinalização podem ser ativadas simultaneamente dentro de uma mesma célula. Partindo desse pressuposto, especulamos que pudesse haver uma comunicação entre a via de sinalização do TCR e a dos EPs/PGE 2 que resultasse em uma sensibilização do linfócito ao processo de apoptose, e para isso utilizamos o modelo de AICD, mas nenhum efeito foi encontrado.

Apesar dos resultados preliminares terem apontado um efeito de sensibilização pela $\mathrm{PGE}_{2}$, é importante ressaltar que, diferente do modelo utilizado neste trabalho, os experimentos iniciais foram realizados com anticorpos agonistas anti-FAS (clone Jo2) e não com o CD95L solúvel (101). A princípio, seria razoável pensar que tanto a molécula solúvel quanto os anticorpos agonistas deveriam induzir o processo de apoptose da mesma forma, uma vez que ambos ligam-se ao receptor FAS e simulam a interação entre FAS/FASL que ocorre fisiologicamente. Entretanto, dados da literatura demonstram claramente que anticorpos agonistas e ligantes solúveis podem se comportar de forma diferente em determinadas situações (112-113). É o que foi observado, por exemplo, quando o tratamento foi realizado com CD95L e não com anticorpos agonistas, em que tanto as células Tipo I quanto as células Tipo II se comportaram da mesma forma frente a um estímulo via FAS. Além disso, essa diferença pode ser evidenciada também entre diferentes construções do CD95L solúvel. Por exemplo, quando o tratamento foi realizado com CD95L acoplado ao epítopo FLAG (fluoresceinated antigen) mais anticorpo antiFLAG, o qual simula a ligação de CD95L próprio acoplado à membrana, também não foram encontradas diferenças entre células Tipo I e Tipo II. Porém, quando foram utilizadas formas altamente ativas de CD95L, fundido com LZ-CD95L (leucine 
zipper tagged CD95L) novamente ficou clara a existência de dois tipos distintos de células a partir da sinalização via FAS (60).

Portanto, concluímos que neste modelo em que a apoptose é induzida pelo tratamento com CD95L solúvel em hibridomas de linfócitos T DO11.10, a PGE 2 não foi capaz de causar qualquer tipo de sensibilização ao processo de apoptose. Entretanto, é de extrema importância uma investigação futura dessa sensibilização em um modelo de indução de apoptose pelo tratamento com anticorpos agonistas anti-FAS. Só então poderemos concluir se realmente não há nenhum efeito de sensibilização ou se a diferença está na maneira como a apoptose é induzida.

Ao investigar a sensibilização ao processo de apoptose em linhagens celulares denominadas de Tipo I e Tipo II, algumas considerações devem ser feitas. Em primeiro lugar, as linhagens utilizadas neste trabalho foram previamente caracterizadas como tais, através do efeito da superexpressão de BCL-2 e/ou BCL$X_{L}$ na indução de apoptose pela via extrínseca $(44,114)$, fenótipo que pôde ser comprovado no presente trabalho através de western blot e citometria de fluxo. É importante salientar que, apesar de linfoblastos (63) e pró-mielócitos se comportarem como células Tipo I em um estado fisiológico in vivo, essas células foram derivadas dos tumores de leucemia linfoblástica aguda (CEM) e leucemia mielóide aguda (HL-60), respectivamente, passando a se comportar como células Tipo II. Já SKW.6.4 é uma linhagem celular de linfócito B transformado pelo EBV que se comporta como uma célula Tipo I (44).

Foi demonstrado por western blot que as células selvagens apresentam expressão de EP3, mas praticamente nenhuma expressão de EP1, EP2 e EP4, os quais estão levemente aumentados em células transfectadas com as proteínas

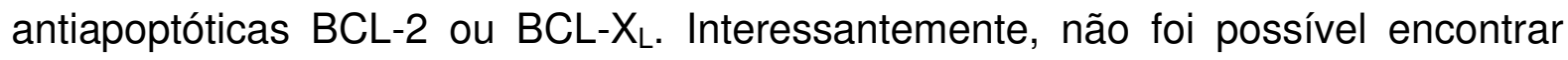
dados na literatura que expliquem esse acontecimento. Experimentos posteriores serão realizados com o intuito de investigar mais profundamente essa relação, confirmando se a superexpressão dessas proteínas realmente altera a expressão dos receptores específicos para a prostaglandina e qual seria a relevância biológica dessa descoberta.

Com base nos dados encontrados, podemos concluir que a $\mathrm{PGE}_{2}$ não é capaz de sensibilizar linhagens celulares Tipo I e Tipo II ao processo de apoptose induzida por anticorpo agonista anti-FAS e, consequentemente, também não é 
capaz de realizar a conversão de células Tipo II em células Tipo I. Uma vez que essas células apresentaram baixa expressão dos receptores EP2 e EP4, os receptores de interesse no processo se sensibilização aqui investigado, a forsk foi utilizada como controle positivo, a fim de excluir a possibilidade da prostaglandina não estar sendo reconhecida adequadamente. Entretanto, nem a forsk foi capaz de induzir sensibilização nas células testadas.

É importante ressaltar que nessas linhagens celulares humanas, a indução de apoptose foi realizada pelo tratamento com anticorpos agonistas anti-FAS (clone $\mathrm{CH} 11)$ e não com o CD95L como no caso dos hibridomas murinos DO11.10. Entretanto, neste caso, o tratamento com o próprio anticorpo agonista não foi capaz de causar qualquer sensibilização ou resistência ao processo de apoptose. Embora a $P G E_{2}$ não tenha sido capaz de exercer nenhum efeito de sensibilização nas linhagens testadas nem tenha realizado a conversão dessas células, é importante continuar a busca por novas moléculas capazes de realizar tal conversão e investigar os mecanismos envolvidos nesse processo. Isso seria de grande importância para uma futura modulação da morte mediada por FAS. 


\section{CONCLUSÕES}

$\checkmark$ A PGE 2 não foi capaz de sensibilizar hibridomas de linfócitos T DO11.10 a apoptose induzida pelo tratamento com CD95L solúvel;

$\checkmark$ A PGE $E_{2}$ não foi capaz de sensibilizar linhagens celulares Tipo I e Tipo II ao processo de apoptose induzida pelo tratamento com anticorpos agonistas anti-FAS e, consequentemente, também não é capaz de realizar a conversão de células Tipo II em células Tipo I. 


\section{REFERÊNCIAS ${ }^{1}$}

1. Danial NN, Korsmeyer SJ. Cell death: critical control points. Cell. 2004 Jan 23;116(2):205-19.

2. Yeretssian G, Labbe K, Saleh M. Molecular regulation of inflammation and cell death. Cytokine. 2008 Sep;43(3):380-90.

3. Opferman JT. Apoptosis in the development of the immune system. Cell Death Differ. 2008 Feb;15(2):234-42.

4. Kerr JF, Wyllie AH, Currie AR. Apoptosis: a basic biological phenomenon with wide-ranging implications in tissue kinetics. Br J Cancer. 1972 Aug;26(4):239-57.

5. Taylor RC, Cullen SP, Martin SJ. Apoptosis: controlled demolition at the cellular level. Nature Reviews. 2008 Mar;9(3):231-41.

6. Kroemer G, Galluzzi L, Vandenabeele P, Abrams J, Alnemri ES, Baehrecke $\mathrm{EH}$, et al. Classification of cell death: recommendations of the Nomenclature Committee on Cell Death 2009. Cell Death Differ. 2009 Jan;16(1):3-11.

7. Martin SJ, Reutelingsperger CP, McGahon AJ, Rader JA, van Schie RC, LaFace DM, et al. Early redistribution of plasma membrane phosphatidylserine is a general feature of apoptosis regardless of the initiating stimulus: inhibition by overexpression of Bcl-2 and Abl. The Journal of Experimental Medicine. $1995 \mathrm{Nov}$ 1;182(5):1545-56.

8. Miyanishi M, Tada K, Koike M, Uchiyama Y, Kitamura T, Nagata S. Identification of Tim4 as a phosphatidylserine receptor. Nature. 2007 Nov 15;450(7168):435-9.

9. Kobayashi N, Karisola P, Pena-Cruz V, Dorfman DM, Jinushi M, Umetsu SE, et al. TIM-1 and TIM-4 glycoproteins bind phosphatidylserine and mediate uptake of apoptotic cells. Immunity. 2007 Dec;27(6):927-40.

10. Savill J, Gregory C. Apoptotic PS to phagocyte TIM-4: eat me. Immunity. 2007 Dec;27(6):830-2.

\footnotetext{
${ }^{1}$ De acordo com:

International Committee of Medical Journal Editors. Uniform requirements for manuscripts submitted to Biomedical Journal: sample references. Available from: http://www.icmje.org [2007 May 22].
} 
11. Strasser A, O'Connor L, Dixit VM. Apoptosis signaling. Annu Rev Biochem. 2000;69:217-45.

12. Poon IK, Hulett MD, Parish CR. Molecular mechanisms of late apoptotic/necrotic cell clearance. Cell Death Differ. 2010 Mar;17(3):381-97.

13. Brenner S. The genetics of Caenorhabditis elegans. Genetics. 1974 May;77(1):71-94.

14. Horvitz HR, Sulston JE. Isolation and genetic characterization of cell-lineage mutants of the nematode Caenorhabditis elegans. Genetics. 1980 Oct;96(2):435-54.

15. Ferguson EL, Horvitz HR. Identification and characterization of 22 genes that affect the vulval cell lineages of the nematode Caenorhabditis elegans. Genetics. 1985 May;110(1):17-72.

16. Ellis HM, Horvitz HR. Genetic control of programmed cell death in the nematode C. elegans. Cell. 1986 Mar 28;44(6):817-29.

17. Wickremasinghe RG, Hoffbrand AV. Biochemical and genetic control of apoptosis: relevance to normal hematopoiesis and hematological malignancies. Blood. 1999 Jun 1;93(11):3587-600.

18. Brady GF, Duckett CS. A caspase homolog keeps CED-3 in check. Trends Biochem Sci. 2009 Mar;34(3):104-7.

19. Lettre G, Hengartner MO. Developmental apoptosis in C. elegans: a complex CEDnario. Nature Reviews. 2006 Feb;7(2):97-108.

20. Chipuk JE, Green DR. How do BCL-2 proteins induce mitochondrial outer membrane permeabilization? Trends in Cell Biology. 2008 Apr;18(4):157-64.

21. Lessene G, Czabotar PE, Colman PM. BCL-2 family antagonists for cancer therapy. Nat Rev Drug Discov. 2008 Dec;7(12):989-1000.

22. Martinez-Caballero S, Dejean LM, Kinnally MS, Oh KJ, Mannella CA, Kinnally $\mathrm{KW}$. Assembly of the mitochondrial apoptosis-induced channel, MAC. The Journal of Biological Chemistry. 2009 May 1;284(18):12235-45.

23. Autret $\mathrm{A}$, Martin SJ. Emerging role for members of the $\mathrm{Bcl}-2$ family in mitochondrial morphogenesis. Molecular Cell. 2009 Nov 13;36(3):355-63. 
24. Logue SE, Martin SJ. Caspase activation cascades in apoptosis. Biochem Soc Trans. 2008 Feb;36(Pt 1):1-9.

25. Pop C, Salvesen GS. Human caspases: activation, specificity, and regulation. The Journal of Biological Chemistry. 2009 Aug 14;284(33):21777-81.

26. Oberst A, Dillon CP, Weinlich R, McCormick LL, Fitzgerald P, Pop C, et al. Catalytic activity of the caspase-8-FLIP(L) complex inhibits RIPK3-dependent necrosis. Nature. 2011 Mar 17;471(7338):363-7.

27. Hengartner MO. The biochemistry of apoptosis. Nature. 2000 Oct 12;407(6805):770-6.

28. Amarante-Mendes GP, Green DR. The regulation of apoptotic cell death. Braz J Med Biol Res. 1999 Sep;32(9):1053-61.

29. Itoh N, Nagata S. A novel protein domain required for apoptosis. Mutational analysis of human Fas antigen. The Journal of Biological Chemistry. 1993 May $25 ; 268(15): 10932-7$.

30. Adam-Klages S, Adam D, Janssen O, Kabelitz D. Death receptors and caspases: role in lymphocyte proliferation, cell death, and autoimmunity. Immunologic Research. 2005;33(2):149-66.

31. Chinnaiyan AM, O'Rourke K, Tewari M, Dixit VM. FADD, a novel death domain-containing protein, interacts with the death domain of Fas and initiates apoptosis. Cell. 1995 May 19;81(4):505-12.

32. Muzio M, Stockwell BR, Stennicke HR, Salvesen GS, Dixit VM. An induced proximity model for caspase-8 activation. The Journal of Biological Chemistry. 1998 Jan 30;273(5):2926-30.

33. Kischkel FC, Hellbardt S, Behrmann I, Germer M, Pawlita M, Krammer PH, et al. Cytotoxicity-dependent APO-1 (Fas/CD95)-associated proteins form a deathinducing signaling complex (DISC) with the receptor. The EMBO Journal. 1995 Nov 15;14(22):5579-88.

34. Algeciras-Schimnich A, Shen L, Barnhart BC, Murmann AE, Burkhardt JK, Peter ME. Molecular ordering of the initial signaling events of CD95. Mol Cell Biol. 2002 Jan;22(1):207-20. 
35. Barnhart BC, Lee JC, Alappat EC, Peter ME. The death effector domain protein family. Oncogene. 2003 Nov 24;22(53):8634-44.

36. Irmler M, Thome M, Hahne M, Schneider P, Hofmann K, Steiner V, et al. Inhibition of death receptor signals by cellular FLIP. Nature. 1997 Jul 10;388(6638):190-5.

37. Yu JW, Shi Y. FLIP and the death effector domain family. Oncogene. 2008 Oct 20;27(48):6216-27.

38. Budd RC. Death receptors couple to both cell proliferation and apoptosis. The Journal of Clinical Investigation. 2002 Feb;109(4):437-41.

39. Peter ME. Programmed cell death: Apoptosis meets necrosis. Nature. 2011 Mar 17;471(7338):310-2.

40. Lens SM, Kataoka T, Fortner KA, Tinel A, Ferrero I, MacDonald RH, et al. The caspase 8 inhibitor c-FLIP $(L)$ modulates T-cell receptor-induced proliferation but not activation-induced cell death of lymphocytes. Mol Cell Biol. 2002 Aug;22(15):5419-33.

41. Chen L, Park SM, Tumanov AV, Hau A, Sawada K, Feig C, et al. CD95 promotes tumour growth. Nature. May 27;465(7297):492-6.

42. Chen L, Park SM, Tumanov AV, Hau A, Sawada K, Feig C, et al. CD95 promotes tumour growth. Nature. 2010 May 27;465(7297):492-6.

43. Li H, Zhu H, Xu CJ, Yuan J. Cleavage of BID by caspase 8 mediates the mitochondrial damage in the Fas pathway of apoptosis. Cell. 1998 Aug 21;94(4):491-501.

44. Scaffidi C, Fulda S, Srinivasan A, Friesen C, Li F, Tomaselli KJ, et al. Two CD95 (APO-1/Fas) signaling pathways. The EMBO Journal. 1998 Mar $16 ; 17(6): 1675-87$.

45. Liu X, Kim CN, Yang J, Jemmerson R, Wang X. Induction of apoptotic program in cell-free extracts: requirement for dATP and cytochrome c. Cell. $1996 \mathrm{Jul}$ 12;86(1):147-57. 
46. Li P, Nijhawan D, Budihardjo I, Srinivasula SM, Ahmad M, Alnemri ES, et al. Cytochrome $c$ and dATP-dependent formation of Apaf-1/caspase-9 complex initiates an apoptotic protease cascade. Cell. 1997 Nov 14;91(4):479-89.

47. Zou H, Henzel WJ, Liu X, Lutschg A, Wang X. Apaf-1, a human protein homologous to $\mathrm{C}$. elegans CED-4, participates in cytochrome c-dependent activation of caspase-3. Cell. 1997 Aug 8;90(3):405-13.

48. Enari M, Sakahira H, Yokoyama H, Okawa K, Iwamatsu A, Nagata S. A caspase-activated DNase that degrades DNA during apoptosis, and its inhibitor ICAD. Nature. 1998 Jan 1;391(6662):43-50.

49. Kaufmann SH, Desnoyers S, Ottaviano Y, Davidson NE, Poirier GG. Specific proteolytic cleavage of poly(ADP-ribose) polymerase: an early marker of chemotherapy-induced apoptosis. Cancer Research. 1993 Sep 1;53(17):3976-85.

50. Verhagen AM, Ekert PG, Pakusch M, Silke J, Connolly LM, Reid GE, et al. Identification of DIABLO, a mammalian protein that promotes apoptosis by binding to and antagonizing IAP proteins. Cell. 2000 Jul 7;102(1):43-53.

51. Du C, Fang M, Li Y, Li L, Wang X. Smac, a mitochondrial protein that promotes cytochrome c-dependent caspase activation by eliminating IAP inhibition. Cell. 2000 Jul 7;102(1):33-42.

52. Li LY, Luo X, Wang X. Endonuclease $G$ is an apoptotic DNase when released from mitochondria. Nature. 2001 Jul 5;412(6842):95-9.

53. Kroemer G, Galluzzi L, Brenner C. Mitochondrial membrane permeabilization in cell death. Physiol Rev. 2007 Jan;87(1):99-163.

54. Lartigue L, Kushnareva $Y$, Seong $Y$, Lin H, Faustin B, Newmeyer DD. Caspase-independent mitochondrial cell death results from loss of respiration, not cytotoxic protein release. Mol Biol Cell. 2009 Dec;20(23):4871-84.

55. Breckenridge DG, Xue D. Regulation of mitochondrial membrane permeabilization by BCL-2 family proteins and caspases. Current Opinion in Cell Biology. 2004 Dec;16(6):647-52.

56. Vaux DL, Aguila HL, Weissman IL. Bcl-2 prevents death of factor-deprived cells but fails to prevent apoptosis in targets of cell mediated killing. International Immunology. 1992 Jul;4(7):821-4. 
57. Brumatti G, Weinlich R, Chehab CF, Yon M, Amarante-Mendes GP. Comparison of the anti-apoptotic effects of $\mathrm{Bcr}-\mathrm{Abl}, \mathrm{Bcl}-2$ and $\mathrm{Bcl}-\mathrm{x}(\mathrm{L})$ following diverse apoptogenic stimuli. FEBS Lett. 2003 Apr 24;541(1-3):57-63.

58. Huang DC, Cory S, Strasser A. Bcl-2, Bcl-XL and adenovirus protein E1B19kD are functionally equivalent in their ability to inhibit cell death. Oncogene. 1997 Jan 30;14(4):405-14.

59. Chao DT, Linette GP, Boise LH, White LS, Thompson CB, Korsmeyer SJ. $\mathrm{Bcl}-\mathrm{XL}$ and $\mathrm{Bcl}-2$ repress a common pathway of cell death. The Journal of Experimental Medicine. 1995 Sep 1;182(3):821-8.

60. Barnhart BC, Alappat EC, Peter ME. The CD95 type I/type II model. Seminars in Immunology. 2003 Jun;15(3):185-93.

61. McKenzie MD, Carrington EM, Kaufmann T, Strasser A, Huang DC, Kay TW, et al. Proapoptotic BH3-only protein Bid is essential for death receptor-induced apoptosis of pancreatic beta-cells. Diabetes. 2008 May;57(5):1284-92.

62. Yin XM, Wang K, Gross A, Zhao Y, Zinkel S, Klocke B, et al. Bid-deficient mice are resistant to Fas-induced hepatocellular apoptosis. Nature. 1999 Aug 26;400(6747):886-91.

63. Moreno MB, Memon SA, Zacharchuk CM. Apoptosis signaling pathways in normal T cells: differential activity of Bcl-2 and IL-1beta-converting enzyme family protease inhibitors on glucocorticoid- and Fas-mediated cytotoxicity. J Immunol. 1996 Nov 1;157(9):3845-9.

64. Tsujimoto $\mathrm{Y}$, Cossman J, Jaffe E, Croce CM. Involvement of the bcl-2 gene in human follicular lymphoma. Science (New York, NY. 1985 Jun 21;228(4706):1440-3.

65. Ciardiello F, Tortora G. Inhibition of bcl-2 as cancer therapy. Ann Oncol. 2002 Apr;13(4):501-2.

66. Vanasse GJ, Winn RK, Rodov S, Zieske AW, Li JT, Tupper JC, et al. Bcl-2 overexpression leads to increases in suppressor of cytokine signaling-3 expression in B cells and de novo follicular lymphoma. Mol Cancer Res. 2004 Nov;2(11):620-31.

67. Brumatti G, Yon M, Castro FA, Bueno-da-Silva AE, Jacysyn JF, Brunner T, et al. Conversion of CD95 (Fas) Type II into Type I signaling by sub-lethal doses of cycloheximide. Experimental Cell Research. 2008 Feb 1;314(3):554-63. 
68. Jost PJ, Grabow S, Gray D, McKenzie MD, Nachbur U, Huang DC, et al. XIAP discriminates between type I and type II FAS-induced apoptosis. Nature. 2009 Aug 20;460(7258):1035-9.

69. Lacour S, Hammann A, Grazide S, Lagadic-Gossmann D, Athias A, Sergent $\mathrm{O}$, et al. Cisplatin-induced CD95 redistribution into membrane lipid rafts of HT29 human colon cancer cells. Cancer Research. 2004 May 15;64(10):3593-8.

70. Dykstra M, Cherukuri A, Sohn HW, Tzeng SJ, Pierce SK. Location is everything: lipid rafts and immune cell signaling. Annu Rev Immunol. 2003;21:45781.

71. Muppidi JR, Siegel RM. Ligand-independent redistribution of Fas (CD95) into lipid rafts mediates clonotypic T cell death. Nat Immunol. 2004 Feb;5(2):182-9.

72. Eramo A, Sargiacomo M, Ricci-Vitiani L, Todaro M, Stassi G, Messina CG, et al. CD95 death-inducing signaling complex formation and internalization occur in lipid rafts of type I and type II cells. Eur J Immunol. 2004 Jul;34(7):1930-40.

73. Zhu J, Paul WE. CD4 T cells: fates, functions, and faults. Blood. 2008 Sep 1;112(5):1557-69.

74. Paul WE, Seder RA. Lymphocyte responses and cytokines. Cell. 1994 Jan $28 ; 76(2): 241-51$.

75. Jackson CE, Puck JM. Autoimmune lymphoproliferative syndrome, a disorder of apoptosis. Curr Opin Pediatr. 1999 Dec;11(6):521-7.

76. Siegel RM, Frederiksen JK, Zacharias DA, Chan FK, Johnson M, Lynch D, et al. Fas preassociation required for apoptosis signaling and dominant inhibition by pathogenic mutations. Science (New York, NY. 2000 Jun 30;288(5475):2354-7.

77. Green DR. Fas Bim boom! Immunity. 2008 Feb;28(2):141-3.

78. Badley AD, Parato K, Cameron DW, Kravcik S, Phenix BN, Ashby D, et al. Dynamic correlation of apoptosis and immune activation during treatment of HIV infection. Cell Death Differ. 1999 May;6(5):420-32.

79. Brenner D, Krammer PH, Arnold R. Concepts of activated T cell death. Crit Rev Oncol Hematol. 2008 Apr;66(1):52-64. 
80. Hildeman DA, Zhu Y, Mitchell TC, Bouillet P, Strasser A, Kappler J, et al. Activated $\mathrm{T}$ cell death in vivo mediated by proapoptotic bcl-2 family member bim. Immunity. 2002 Jun;16(6):759-67.

81. O'Connor L, Strasser A, O'Reilly LA, Hausmann G, Adams JM, Cory S, et al. Bim: a novel member of the Bcl-2 family that promotes apoptosis. The EMBO Journal. 1998 Jan 15;17(2):384-95.

82. Brunner T, Mogil RJ, LaFace D, Yoo NJ, Mahboubi A, Echeverri F, et al. Cellautonomous Fas (CD95)/Fas-ligand interaction mediates activation-induced apoptosis in T-cell hybridomas. Nature. 1995 Feb 2;373(6513):441-4.

83. Ju ST, Panka DJ, Cui $H$, Ettinger $R$, el-Khatib $M$, Sherr $D H$, et al. Fas(CD95)/FasL interactions required for programmed cell death after T-cell activation. Nature. 1995 Feb 2;373(6513):444-8.

84. Dhein J, Walczak H, Baumler C, Debatin KM, Krammer PH. Autocrine T-cell suicide mediated by APO-1/(Fas/CD95). Nature. 1995 Feb 2;373(6513):438-41.

85. Weinlich R, Bortoluci KR, Chehab CF, Serezani CH, Ulbrich AG, PetersGolden M, et al. TLR4/MYD88-dependent, LPS-induced synthesis of PGE2 by macrophages or dendritic cells prevents anti-CD3-mediated CD95L upregulation in T cells. Cell Death Differ. 2008 Dec;15(12):1901-9.

86. Porter BO, Malek TR. Prostaglandin E2 inhibits T cell activation-induced apoptosis and Fas-mediated cellular cytotoxicity by blockade of Fas-ligand induction. Eur J Immunol. 1999 Jul;29(7):2360-5.

87. Hildeman DA, Zhu Y, Mitchell TC, Kappler J, Marrack P. Molecular mechanisms of activated $T$ cell death in vivo. Curr Opin Immunol. 2002 Jun;14(3):354-9.

88. Hata AN, Breyer RM. Pharmacology and signaling of prostaglandin receptors: multiple roles in inflammation and immune modulation. Pharmacol Ther. 2004 Aug;103(2):147-66.

89. Kobayashi T, Narumiya S. Function of prostanoid receptors: studies on knockout mice. Prostaglandins Other Lipid Mediat. 2002 Aug;68-69:557-73.

90. Dubois RN, Abramson SB, Crofford L, Gupta RA, Simon LS, Van De Putte LB, et al. Cyclooxygenase in biology and disease. Faseb J. 1998 Sep;12(12):106373. 
91. Smith WL. The eicosanoids and their biochemical mechanisms of action. Biochem J. 1989 Apr 15;259(2):315-24.

92. Su $\mathrm{Y}$, Huang $\mathrm{X}$, Raskovalova $\mathrm{T}$, Zacharia L, Lokshin A, Jackson $\mathrm{E}$, et al. Cooperation of adenosine and prostaglandin E2 (PGE2) in amplification of cAMPPKA signaling and immunosuppression. Cancer Immunol Immunother. 2008 Nov;57(11):1611-23.

93. Nishigaki N, Negishi M, Ichikawa A. Two Gs-coupled prostaglandin E receptor subtypes, EP2 and EP4, differ in desensitization and sensitivity to the metabolic inactivation of the agonist. Mol Pharmacol. 1996 Oct;50(4):1031-7.

94. Breyer RM. Prostaglandin EP(1) receptor subtype selectivity takes shape. Mol Pharmacol. 2001 Jun;59(6):1357-9.

95. Tilley SL, Coffman TM, Koller BH. Mixed messages: modulation of inflammation and immune responses by prostaglandins and thromboxanes. The Journal of Clinical Investigation. 2001 Jul;108(1):15-23.

96. Harris SG, Padilla J, Koumas L, Ray D, Phipps RP. Prostaglandins as modulators of immunity. Trends Immunol. 2002 Mar;23(3):144-50.

97. O'Callaghan G, Kelly J, Shanahan F, Houston A. Prostaglandin E2 stimulates Fas ligand expression via the EP1 receptor in colon cancer cells. Br J Cancer. 2008 Aug 5;99(3):502-12.

98. Kim H, Rhee SH, Pothoulakis C, Lamont JT. Inflammation and apoptosis in Clostridium difficile enteritis is mediated by PGE2 up-regulation of Fas ligand. Gastroenterology. 2007 Sep;133(3):875-86.

99. Yarovinsky TO, Hunninghake GW. Lung fibroblasts inhibit activation-induced death of T cells through PGE(2)-dependent mechanisms. Am J Physiol Lung Cell Mol Physiol. 2001 Nov;281(5):L1248-56.

100. Huang SK, White ES, Wettlaufer SH, Grifka H, Hogaboam CM, Thannickal VJ, et al. Prostaglandin $\mathrm{E}(2)$ induces fibroblast apoptosis by modulating multiple survival pathways. FASEB J. 2009 Dec;23(12):4317-26.

101. Weinlich $R$, . Regulação do CD95L por $\mathrm{PGE}_{2}$ e seu impacto na morte de linfócitos $T$ [tese (Doutorado em Imunologia)]. São Paulo (Brasil): Instituto de Ciências Biomédicas da Universidade de São Paulo; 2008. 
102. Legembre P, Daburon S, Moreau P, Moreau JF, Taupin JL. Modulation of Fas-mediated apoptosis by lipid rafts in T lymphocytes. J Immunol. 2006 Jan 15;176(2):716-20.

103. Luciani F, Matarrese P, Giammarioli AM, Lugini L, Lozupone F, Federici C, et al. CD95/phosphorylated ezrin association underlies HIV-1 GP120/LL-2-induced susceptibility to CD95(APO-1/Fas)-mediated apoptosis of human resting CD4(+)T lymphocytes. Cell Death Differ. 2004 May;11(5):574-82.

104. Legembre P, Daburon S, Moreau P, Ichas F, de Giorgi F, Moreau JF, et al. Amplification of Fas-mediated apoptosis in type II cells via microdomain recruitment. Mol Cell Biol. 2005 Aug;25(15):6811-20.

105. Marrack P, Shimonkevitz R, Hannum C, Haskins K, Kappler J. The major histocompatibility complex-restricted antigen receptor on T cells. IV. An antiidiotypic antibody predicts both antigen and I-specificity. The Journal of Experimental Medicine. 1983 Nov 1;158(5):1635-46.

106. Leo O, Foo M, Sachs DH, Samelson LE, Bluestone JA. Identification of a monoclonal antibody specific for a murine T3 polypeptide. Proceedings of the National Academy of Sciences of the United States of America. 1987 Mar;84(5):1374-8.

107. Sugimoto $Y$, Narumiya S. Prostaglandin E receptors. The Journal of Biological Chemistry. 2007 Apr 20;282(16):11613-7.

108. Peter ME, Budd RC, Desbarats J, Hedrick SM, Hueber AO, Newell MK, et al. The CD95 receptor: apoptosis revisited. Cell. 2007 May 4;129(3):447-50.

109. Brown DM, Warner GL, Ales-Martinez JE, Scott DW, Phipps RP. Prostaglandin E2 induces apoptosis in immature normal and malignant B lymphocytes. Clinical Immunology and Immunopathology. 1992 Jun;63(3):221-9.

110. Schmitz I, Krueger A, Baumann S, Schulze-Bergkamen $\mathrm{H}$, Krammer $\mathrm{PH}$, Kirchhoff S. An IL-2-dependent switch between CD95 signaling pathways sensitizes primary human $\mathrm{T}$ cells toward CD95-mediated activation-induced cell death. $\mathrm{J}$ Immunol. 2003 Sep 15;171(6):2930-6.

111. Krammer PH. CD95's deadly mission in the immune system. Nature. 2000 Oct 12;407(6805):789-95. 
112. LA OR, Tai L, Lee L, Kruse EA, Grabow S, Fairlie WD, et al. Membranebound Fas ligand only is essential for Fas-induced apoptosis. Nature. 2009 Oct 1;461(7264):659-63.

113. Janssen O, Qian J, Linkermann A, Kabelitz D. CD95 ligand--death factor and costimulatory molecule? Cell Death Differ. 2003 Nov;10(11):1215-25.

114. Furukawa $\mathrm{Y}$, Iwase S, Terui $\mathrm{Y}$, Kikuchi J, Sakai T, Nakamura M, et al. Transcriptional activation of the cdc2 gene is associated with Fas-induced apoptosis of human hematopoietic cells. The Journal of Biological Chemistry. 1996 Nov 8;271(45):28469-77. 